\title{
LEVEL II SCOUR ANALYSIS FOR BRIDGE 50 (WALLTH00600050) on TOWN HIGHWAY 60, crossing OTTER CREEK, WALLINGFORD, VERMONT
}

Open-File Report 98-255

Prepared in cooperation with

VERMONT AGENCY OF TRANSPORTATION

and

FEDERAL HIGHWAY ADMINISTRATION

U.S. Department of the Interior

U.S. Geological Survey

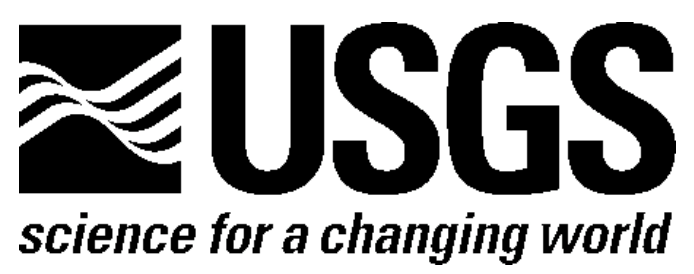




\section{LEVEL II SCOUR ANALYSIS FOR BRIDGE 50 (WALLTH00600050) on TOWN HIGHWAY 60, crossing OTTER CREEK, WALLINGFORD, VERMONT By MICHAEL A. IVANOFF}

U.S. Geological Survey Open-File Report 98-255

Prepared in cooperation with

VERMONT AGENCY OF TRANSPORTATION

and

FEDERAL HIGHWAY ADMINISTRATION 


\title{
U.S. DEPARTMENT OF THE INTERIOR BRUCE BABBITT, Secretary
}

\author{
U.S. GEOLOGICAL SURVEY
}

Thomas J. Casadevall, Acting Director

For additional information write to:

District Chief

U.S. Geological Survey 361 Commerce Way

Pembroke, NH 03275-3718
Copies of this report may be purchased from:

U.S. Geological Survey

Branch of Information Services

Open-File Reports Unit

Box 25286

Denver, CO 80225-0286 


\section{CONTENTS}

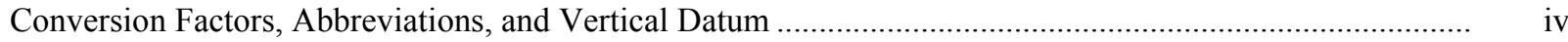

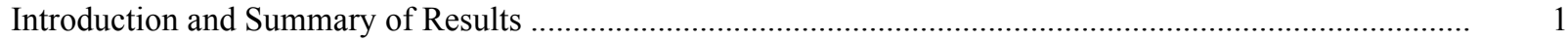

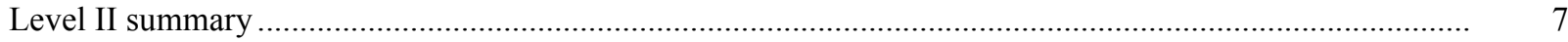

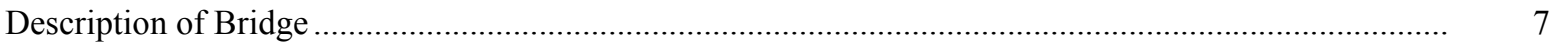

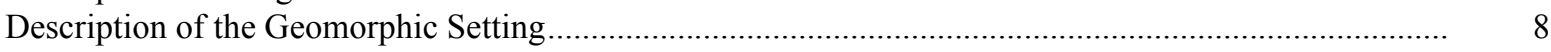

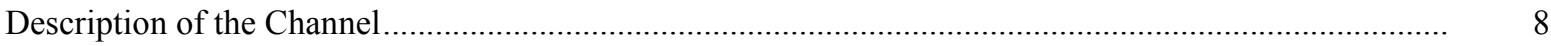

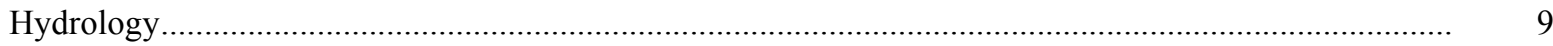

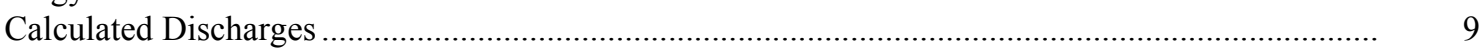

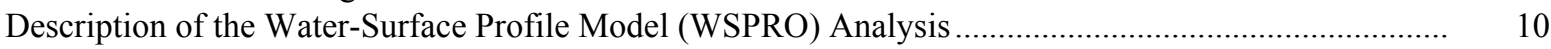

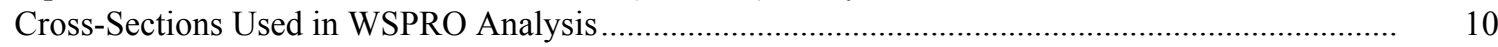

Data and Assumptions Used in WSPRO Model ........................................................................ 11

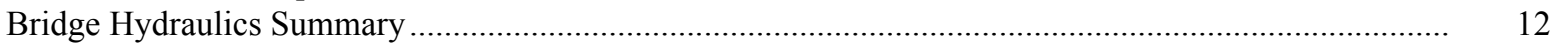

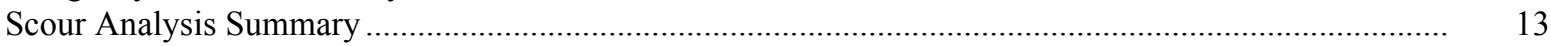

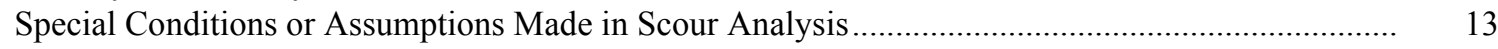

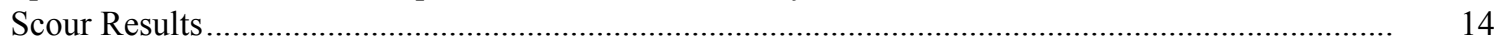

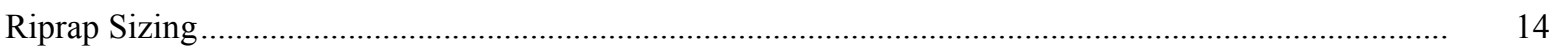

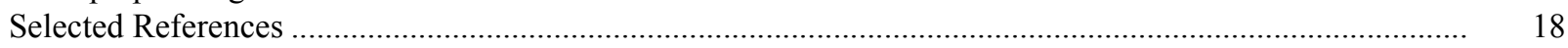

Appendices:

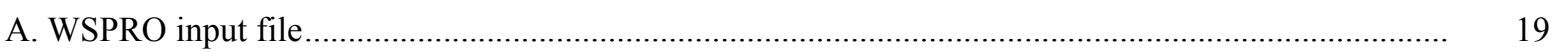

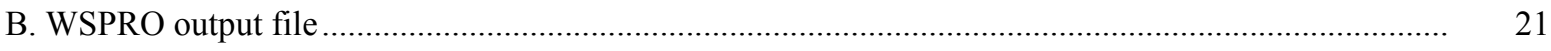

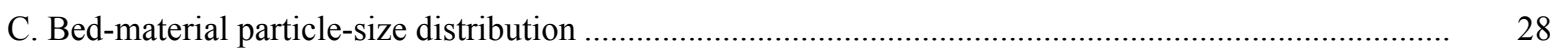

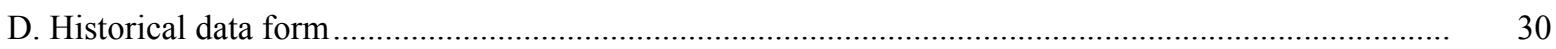

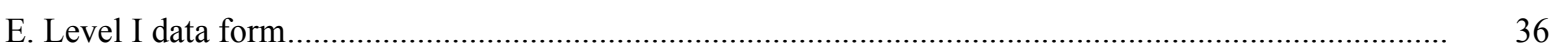

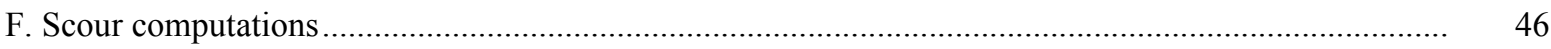

\section{FIGURES}

1. Map showing location of study area on USGS 1:24,000 scale map

2. Map showing location of study area on Vermont Agency of Transportation town highway map .....

3. Structure WALLTH00600050 viewed from upstream (September 26, 1995)

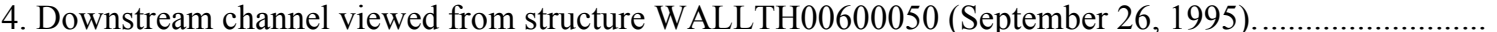

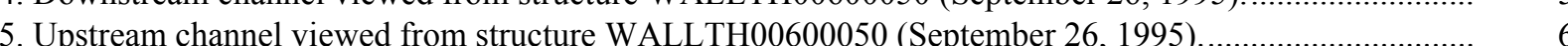

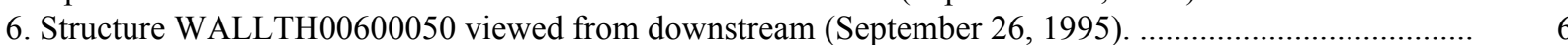

7. Water-surface profiles for the 100- and 500-year discharges at structure

WALLTH00600050 on Town Highway 60, crossing Otter Creek,

Wallingford, Vermont.

8. Scour elevations for the 100- and 500-year discharges at structure

WALLTH00600050 on Town Highway 60, crossing Otter Creek,

Wallingford, Vermont.

\section{TABLES}

1. Remaining footing/pile depth at abutments for the 100-year discharge at structure

WALLTH00600050 on Town Highway 60, crossing Otter Creek,

Wallingford, Vermont

2. Remaining footing/pile depth at abutments for the 500-year discharge at structure

WALLTH00600050 on Town Highway 60, crossing Otter Creek,

Wallingford, Vermont 


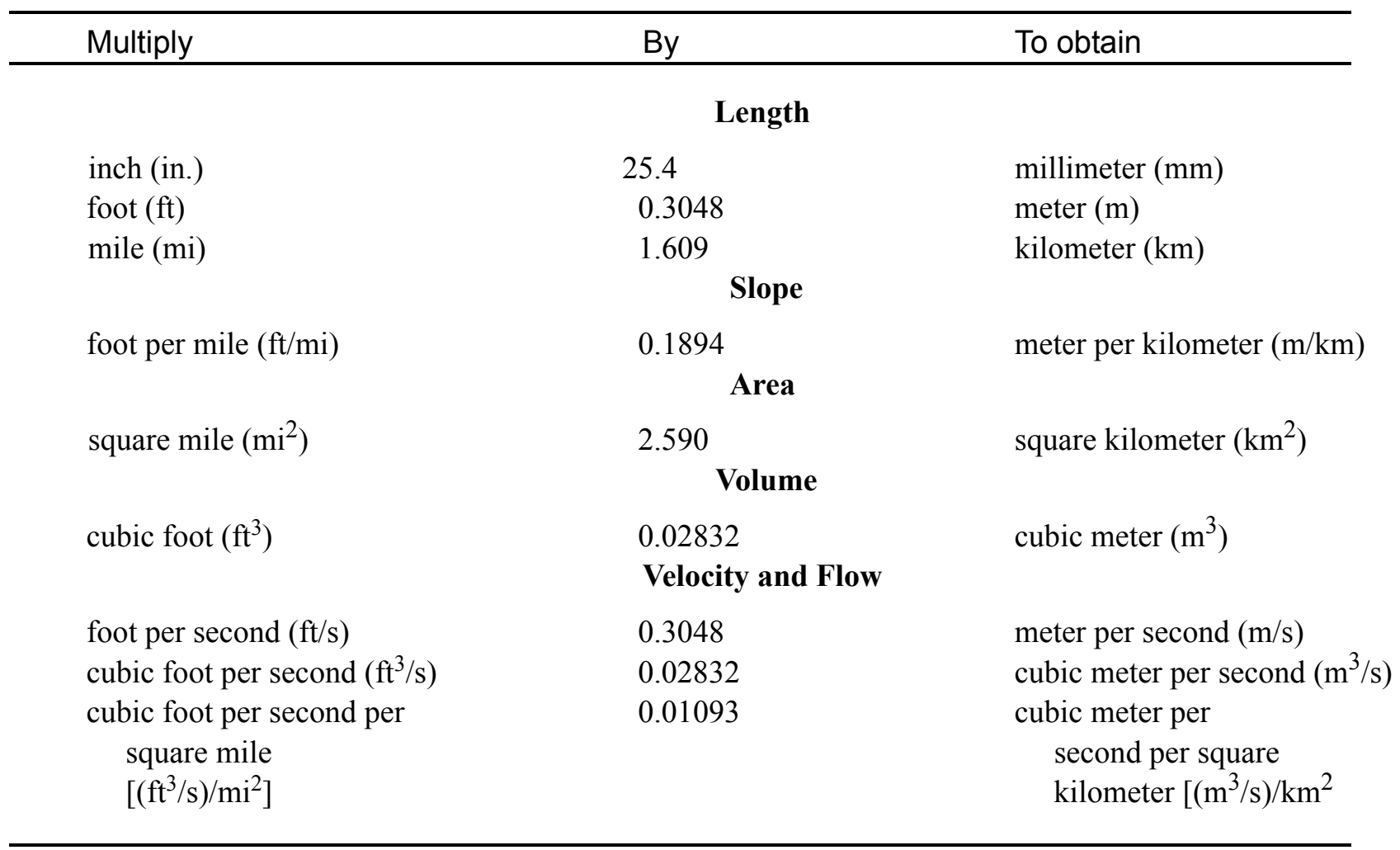

\section{OTHER ABBREVIATIONS}

$\begin{array}{lrlr}\mathrm{BF} & \text { bank full } & \text { LWW } & \text { left wingwall } \\ \mathrm{cfs} & \text { cubic feet per second } & \text { Max } & \text { maximum } \\ \mathrm{D}_{50} & \text { median diameter of bed material } & \text { MC } & \text { main channel } \\ \mathrm{DS} & \text { downstream } & \text { RAB } & \text { right abutment } \\ \mathrm{elev} & \text { elevation } & \text { RABUT } & \text { face of right abutment } \\ \mathrm{f} / \mathrm{p} & \text { flood plain } & \text { RB } & \text { right bank } \\ \mathrm{ft} & \text { square feet } & \text { ROB } & \text { right overbank } \\ \mathrm{ft} / \mathrm{ft} & \text { feet per foot } & \text { RWW } & \text { right wingwall } \\ \mathrm{FEMA} & \text { Federal Emergency Management Agency } & \text { TH } & \text { town highway } \\ \mathrm{FHWA} & \text { Federal Highway Administration } & \text { UB } & \text { under bridge } \\ \mathrm{JCT} & \text { junction } & \text { US } & \text { upstream } \\ \text { LAB } & \text { left abutment } & \text { USGS } & \text { United States Geological Survey } \\ \text { LABUT } & \text { face of left abutment } & \text { VTAOT } & \text { Vermont Agency of Transportation } \\ \text { LB } & \text { left bank } & \text { WSPRO } & \text { water-surface profile model } \\ \text { LOB } & \text { left overbank } & \text { yr } & \text { year }\end{array}$

In this report, the words "right" and "left" refer to directions that would be reported by an observer facing downstream. Sea level: In this report, "sea level" refers to the National Geodetic Vertical Datum of 1929-- a geodetic datum derived from a general adjustment of the first-order level nets of the United States and Canada, formerly called Sea Level Datum of 1929.

In the appendices, the above abbreviations may be combined. For example, USLB would represent upstream left bank. 


\title{
LEVEL II SCOUR ANALYSIS FOR BRIDGE 50 (WALLTH00600050) ON TOWN HIGHWAY 60, CROSSING OTTER CREEK, WALLINGFORD, VERMONT
}

\author{
By Michael A. Ivanoff
}

\section{INTRODUCTION AND SUMMARY OF RESULTS}

This report provides the results of a detailed Level II analysis of scour potential at structure WALLTH00600050 on Town Highway 60 crossing Otter Creek, Wallingford, Vermont (figures 1-8). A Level II study is a basic engineering analysis of the site, including a quantitative analysis of stream stability and scour (FHWA, 1993). Results of a Level I scour investigation also are included in appendix $\mathrm{E}$ of this report. A Level I investigation provides a qualitative geomorphic characterization of the study site. Information on the bridge, gleaned from Vermont Agency of Transportation (VTAOT) files, was compiled prior to conducting Level I and Level II analyses and is found in appendix D.

The site is in the Taconic section of the New England physiographic province in southcentral Vermont. The $103-\mathrm{mi}^{2}$ drainage area is in a predominantly rural and forested basin. In the vicinity of the study site, the surface cover is forest.

In the study area, Otter Creek has an incised, straight channel with a slope of approximately $0.004 \mathrm{ft} / \mathrm{ft}$, an average channel top width of $70 \mathrm{ft}$ and an average bank height of $4 \mathrm{ft}$. The channel bed material ranges from gravel to boulders with a median grain size $\left(D_{50}\right)$ of 94.5 $\mathrm{mm}(0.310 \mathrm{ft})$. The geomorphic assessment at the time of the Level I and Level II site visit on September 26, 1995, indicated that the reach was laterally unstable. There is anabranching up- and downstream with bedrock along the left bank and flow channels with random bars across the channel.

The Town Highway 60 crossing of Otter Creek is a 72-ft-long, one-lane bridge consisting of one 70-foot steel thru-truss span (Vermont Agency of Transportation, written communication, March 22, 1995). The opening length of the structure parallel to the bridge face is $67 \mathrm{ft}$. The bridge is supported by vertical, concrete abutments with wingwalls. The channel is skewed approximately 25 degrees to the opening while the computed openingskew-to-roadway is 5 degrees. 
A scour hole $7.5 \mathrm{ft}$ deeper than the mean thalweg depth was observed along the downstream channel during the Level I assessment. The scour protection measures at the site include type-2 stone fill (less than 36 inches diameter) along the left abutment, upstream left bank, upstream left wingwall, downstream left wingwall, and downstream left bank. Type-3 stone fill (less than 48 inches diameter) was observed along the right abutment. Additional details describing conditions at the site are included in the Level II Summary and appendices D and E.

Scour depths and recommended rock rip-rap sizes were computed using the general guidelines described in Hydraulic Engineering Circular 18 (Richardson and Davis, 1995) for the 100- and 500-year discharges. In addition, the incipient roadway-overtopping discharge was determined and analyzed as another potential worst-case scour scenario. Total scour at a highway crossing is comprised of three components: 1) long-term streambed degradation; 2) contraction scour (due to accelerated flow caused by a reduction in flow area at a bridge) and; 3 ) local scour (caused by accelerated flow around piers and abutments). Total scour is the sum of the three components. Equations are available to compute depths for contraction and local scour and a summary of the results of these computations follows.

Computed contraction scour for all modelled flows was zero feet. Abutment scour ranged from 7.9 to $17.9 \mathrm{ft}$. The worst-case abutment scour occurred at the 500-year discharge. Additional information on scour depths and depths to armoring are included in the section titled "Scour Results". Scoured-streambed elevations, based on the calculated scour depths, are presented in tables 1 and 2. A cross-section of the scour computed at the bridge is presented in figure 8 . Scour depths were calculated assuming an infinite depth of erosive material and a homogeneous particle-size distribution.

It is generally accepted that the Froehlich equation (abutment scour) gives "excessively conservative estimates of scour depths" (Richardson and Davis, 1995, p. 46). Usually, computed scour depths are evaluated in combination with other information including (but not limited to) historical performance during flood events, the geomorphic stability assessment, existing scour protection measures, and the results of the hydraulic analyses. Therefore, scour depths adopted by VTAOT may differ from the computed values documented herein. 


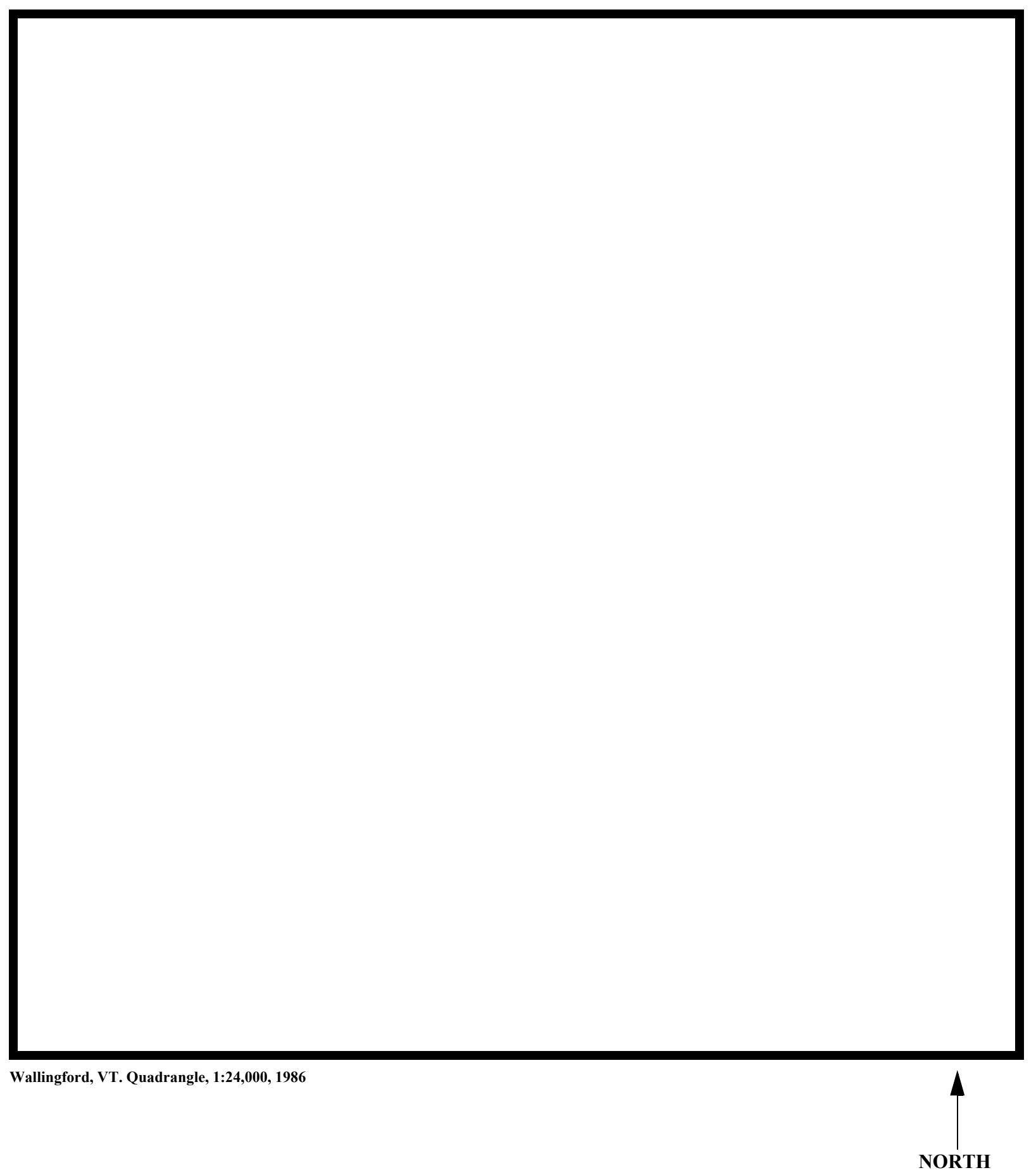

Figure 1. Location of study area on USGS 1:24,000 scale map. 
Figure 2. Location of study area on Vermont Agency of Transportation town highway map. 

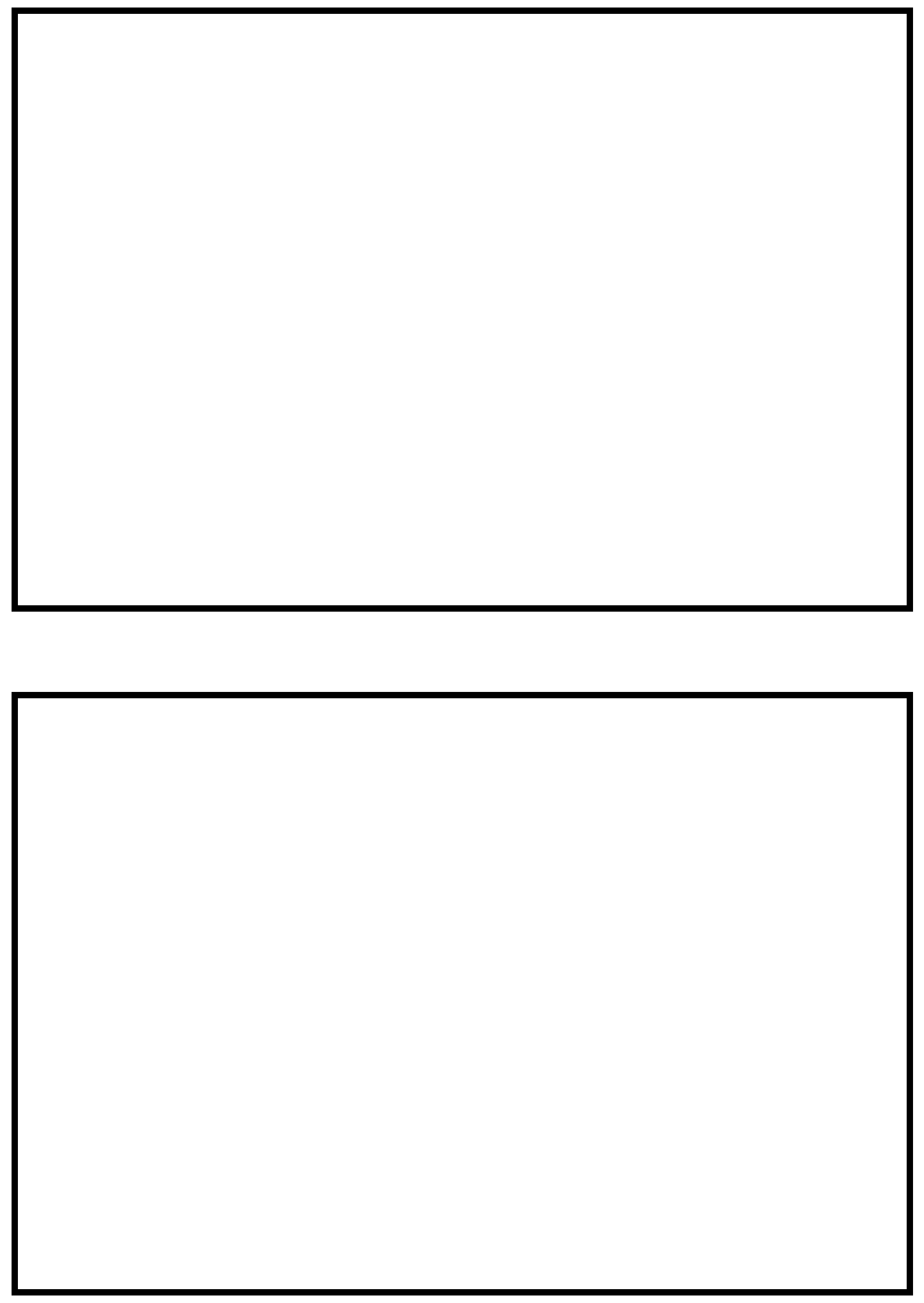

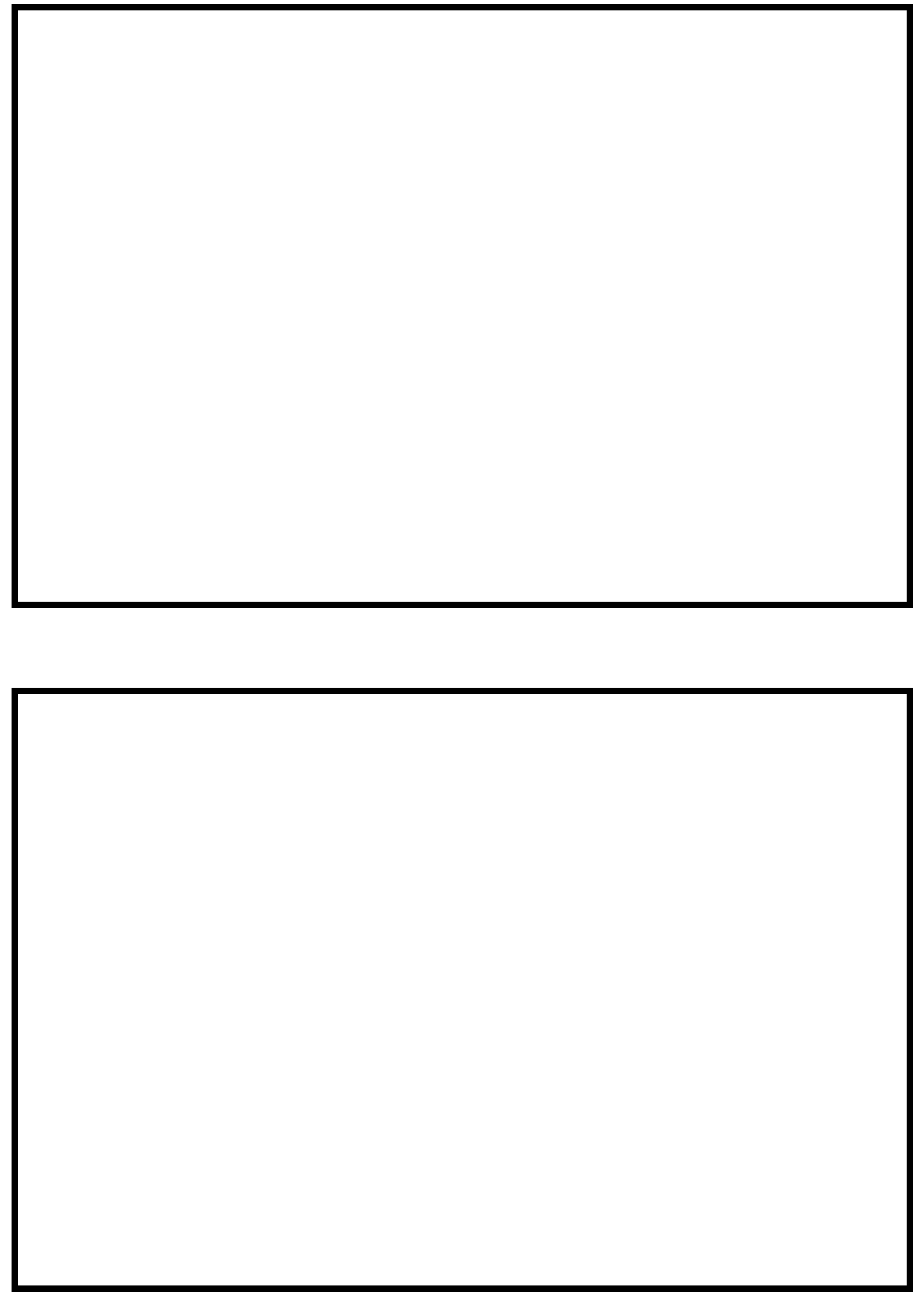


\section{LEVEL II SUMMARY}

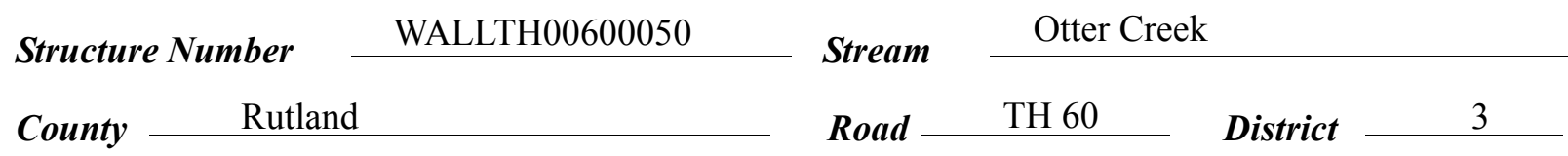

\section{Description of Bridge}

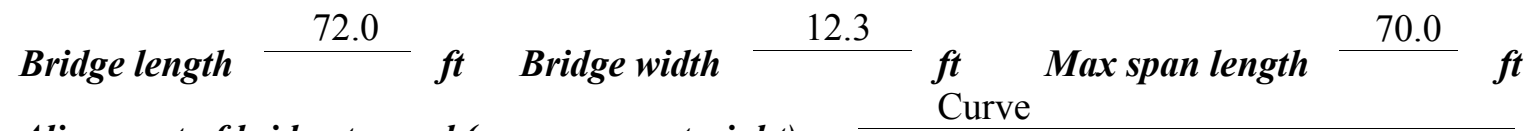

Alignment of bridge to road (on curve or straight)

\section{Abutment type} Vertical, concrete

Stone fill on abutment?

$$
\text { No }
$$

\section{Embankment type}

\section{nacamintinu af atans fill} Type-2, along the entire base length of the left abutment and type-3,

Abutments and wingwalls are concrete.

$\ldots \ldots$

\section{Yes}

Angle
Is bridge skewed to flood flow according to Yes ' survey?

25

There is a mild channel bend in the upstream reach.

Debris accumulation on bridge at time of Level I or Level II site visit:

\begin{tabular}{|c|c|c|}
\hline $\begin{array}{c}\text { Date of insnortinn } \\
9 / 26 / 95 \\
\end{array}$ & $\begin{array}{l}\text { Percent of alhmmal } \\
\text { blocked inortzontatly }\end{array}$ & $\begin{array}{l}\text { Percent of } 0 \\
\text { blocked verticatty }\end{array}$ \\
\hline & 0 & 0 \\
\hline
\end{tabular}

Level I

Moderate. There is some debris caught on the banks and trees

Level II

nel upstream.

Potential for debris

A $6 \mathrm{ft}$ diameter culvert was observed on 9/26/95 through the right road embankment, which has Dossriho anv foaturos noar ar at tho hridoo that mav, affort flow, (includo ahsorvation dato) little affect at high flow. 


\section{Description of the Geomorphic Setting}

General topography The channel is located within a moderate relief valley with a steep valley wall on the left bank and a flood plain on the right bank.

Geomorphic conditions at bridge site: downstream (DS), upstream (US)

Date of inspection $\quad 9 / 26 / 95$

DS left: $\quad$ Steep channel bank and valley wall.

DS right: $\quad$ Steep channel bank and a narrow, irregular flood plain.

US left: $\quad$ Steep channel bank and valley wall.

US right: $\quad$ Mildly sloped channel bank and an irregular flood plain.

\section{Description of the Channel}

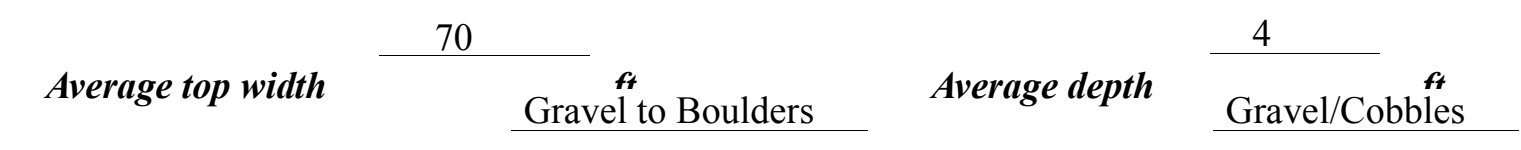

Predominant bed material

Bank material

Perennial, straight

and anabranched stream with semi-alluvial channel boundaries."

$9 / 26 / 95$

Vegetative co 1 Trees and brush.

DS left: $\quad$ Trees and brush.

DS right: $\quad$ Trees and brush.

US left: $\quad$ Trees and brush.

US right: $\quad$ Yes

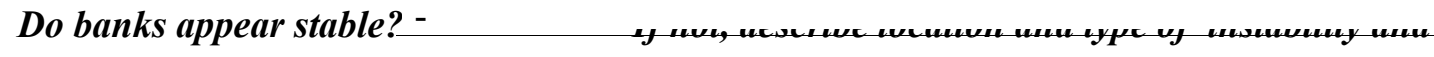

date of observation.

None as of 9/26/95.

Describe any obstructions in channel and date of observation. 


\title{
Hydrology
}

Drainage area $\frac{103}{\boldsymbol{m i}^{2}}$

Percentage of drainage area in physiographic provinces: (approximate)

Physiographic province/section New England/Taconic
Percent of drainage area 100

\begin{abstract}
Is drainage area considered rural or urban?
Rural None. urbanization:-

Describe any significant
\end{abstract}

Yes

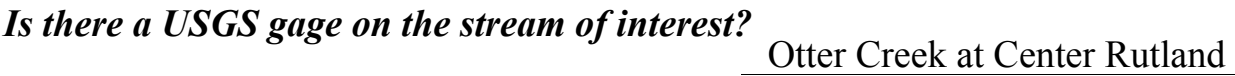
USGS gage description 04282000

USGS gage number 307

Gage drainage area $\quad \mathrm{mi}^{2}$

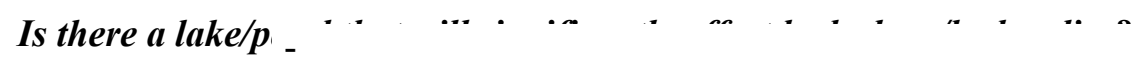

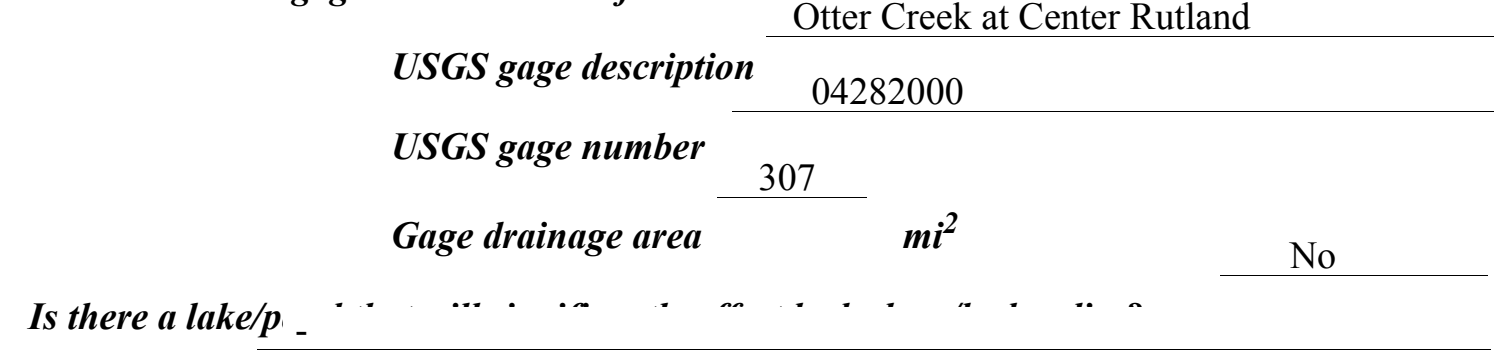

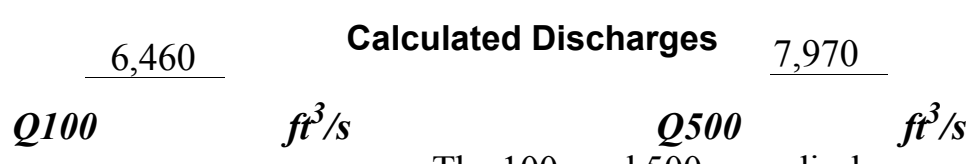

The 100- and 500-year discharges are based on a

drainage area relationship [(103/307/2exp 0.67] with the 100- and 500-year discharges

determined for the downstream (04282000, Otter Creek at Center Rutland) gage for the period

of record from 1928 to 1993. The 100- and 500- year discharges at the gage were developed using a Log-Pearson Type-III analysis of the peak-flow data (Interagency Advisory Committee on Water Data, 1982). The values used were within a range defined by flood frequency curves developed from several empirical methods (Benson, 1962; Johnson and Tasker, 1974; FHWA, 1983; Potter, 1957a\&b; Talbot, 1887). 


\section{Description of the Water-Surface Profile Model (WSPRO) Analysis}

Datum for WSPRO analysis (USGS survey, sea level, VTAOT plans)

USGS survey

Datum tie between USGS survey and VTAOT plans

None

Description of reference marks used to determine USGS datum. $\quad$ RM1 is a chiseled " $X$ "

on top of the downstream end of the right abutment bridge seat (elev. $498.29 \mathrm{ft}$, arbitrary survey

datum). RM2 is a chiseled " $\mathrm{X}$ " on top of the upstream end of the left abutment bridge seat (elev.

$498.59 \mathrm{ft}$, arbitrary survey datum).

\section{Cross-Sections Used in WSPRO Analysis}

\begin{tabular}{cccl}
\hline${ }^{1}$ Cross-section & $\begin{array}{c}\text { Section } \\
\text { Reference } \\
\text { Distance } \\
\text { (SRD) } \text { in feet }\end{array}$ & $\begin{array}{c}{ }^{2} \text { Cross-section } \\
\text { development }\end{array}$ & \multicolumn{1}{c}{ Comments } \\
\hline EXITX & -58 & 1 & $\begin{array}{l}\text { Exit section } \\
\text { Downstream Full-valley } \\
\text { section (Templated from } \\
\text { EXITX) }\end{array}$ \\
FULLV & 0 & 2 & $\begin{array}{l}\text { Bridge section } \\
\text { Road Grade section }\end{array}$ \\
RDWAY & 0 & 1 & $\begin{array}{l}\text { Modelled Approach sec- } \\
\text { tion (Templated from } \\
\text { APTEM) }\end{array}$ \\
APTEM & 8 & 1 & $\begin{array}{l}\text { Approach section as sur- } \\
\text { veyed (Used as a tem- } \\
\text { plate) }\end{array}$ \\
\hline
\end{tabular}

${ }^{1}$ For location of cross-sections see plan-view sketch included with Level I field form, Appendix E.

For more detail on how cross-sections were developed see WSPRO input file. 


\section{Data and Assumptions Used in WSPRO Model}

Hydraulic analyses of the reach were done by use of the Federal Highway Administration's WSPRO step-backwater computer program (Shearman and others, 1986, and Shearman, 1990). The analyses reported herein reflect conditions existing at the site at the time of the study. Furthermore, in the development of the model it was necessary to assume no accumulation of debris or ice at the site. Results of the hydraulic model are presented in the Bridge Hydraulic Summary, appendix B, and figure 7.

Channel roughness factors (Manning's " $n$ ") used in the hydraulic model were estimated using field inspections at each cross section following the general guidelines described by Arcement and Schneider (1989). Final adjustments to the values were made during the modelling of the reach. Channel " $\mathrm{n}$ " values for the reach ranged from 0.040 to 0.060 , and overbank " $\mathrm{n}$ " values ranged from 0.055 to 0.060 .

Normal depth at the exit section (EXITX) was assumed as the starting water surface. This depth was computed by use of the slope-conveyance method outlined in the user's manual for WSPRO (Shearman, 1990). The slope used was $0.0013 \mathrm{ft} / \mathrm{ft}$, which was estimated from the 100-year flood profile from the Flood Insurance Study for the Town of Wallingford, VT (Federal Emergency Management Agency, 1980).

The surveyed approach section (APTEM) was moved along the approach channel slope $(0.0352 \mathrm{ft} / \mathrm{ft})$ to establish the modelled approach section (APPRO), one bridge length upstream of the upstream face as recommended by Shearman and others (1986). This location provides a consistent method for determining scour variables. 


\section{Bridge Hydraulics Summary}

\begin{tabular}{lll} 
Average bridge embankment elevation & 501.0 \\
\cline { 3 - 3 } Average low steel elevation & 498.8 & $\boldsymbol{f t}$
\end{tabular}

100-year discharge $\quad 6,460 \quad \mathrm{ft}^{3} / \mathrm{s}$

Water-surface elevation in bridge opening $\quad 498.0 \quad f t$

Road overtopping? ___ Yes Discharge over road __ $1,500 \quad \mathrm{ft}^{3} / \mathrm{s}$

\begin{tabular}{llll} 
Area of flow in bridge opening & $629 \quad \mathrm{ft}^{2}$ & \\
\cline { 2 - 3 } Average velocity in bridge opening & 7.9 & $\mathrm{ft} / \mathrm{s}$
\end{tabular}

$\begin{array}{lll}\text { Maximum WSPRO tube velocity at bridge } & 9.9 \mathrm{ft} / \mathrm{s}\end{array}$

Water-surface elevation at Approach section with bridge 499.3

Water-surface elevation at Approach section without bridge $\quad 497.4$

Amount of backwater caused by bridge

$1.9, i$

500-year discharge $\quad 7,970 \quad \mathrm{ft}^{3} / \mathrm{s}$

Water-surface elevation in bridge opening

$499.2 \boldsymbol{f t}$

Road overtopping? ___ Yes Discharge over road __ 2,790 $\mathrm{ft}^{3} / \mathrm{s}$

\begin{tabular}{llll} 
Area of flow in bridge opening & 686 & $\mathrm{ft}^{2}$ & \\
\cline { 2 - 4 } Average velocity in bridge opening & & $7.6 \quad \mathrm{ft} / \mathrm{s}$
\end{tabular}

Maximum WSPRO tube velocity at bridge $\quad 9.1$ 's

Water-surface elevation at Approach section with bridge

Water-surface elevation at Approach section without bridge

Amount of backwater caused by bridge $\quad 0.9 \quad, t$

500.1

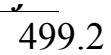

Incipient overtopping discharge $\quad 3,720 \quad \mathrm{ft}^{3} / \mathrm{s}$

Water-surface elevation in bridge opening $495.7 \quad$ it

Area of flow in bridge opening

$479 \quad \mathrm{ft}^{2}$

Average velocity in bridge opening

Maximum WSPRO tube velocity at bridge

$7.8 \mathrm{ft} / \mathrm{s}$

$f t / s$

Water-surface elevation at Approach section with bridge

Water-surface elevation at Approach section without bridge

497.0

Amount of backwater caused by bridge

0.5 . $t$

496.5 


\section{Scour Analysis Summary}

\section{Special Conditions or Assumptions Made in Scour Analysis}

Scour depths were computed using the general guidelines described in Hydraulic Engineering Circular 18 (Richardson and Davis, 1995). Scour depths were calculated assuming an infinite depth of erosive material and a homogeneous particle-size distribution. The results of the scour analyses for the 100- and 500-year discharges are presented in tables 1 and 2 and the scour depths are shown graphically in figure 8 .

Contraction scour for the 100-year and incipient roadway-overtopping discharges was computed by use of the Laursen clear-water contraction scour equation (Richardson and Davis, 1995, p. 32, equation 20). At this site, the 500-year discharge resulted in unsubmerged orifice flow. Contraction scour at bridges with orifice flow is best estimated by use of the Chang pressure-flow scour equation (oral communication, J. Sterling Jones, October 4, 1996). Thus, contraction scour for this discharge was computed by use of the Chang equation (Richardson and Davis, 1995, p. 145-146).

For comparison, contraction scour for the 500-year discharge was also computed by use of the Laursen clear-water contraction scour equation and the Umbrell pressure-flow equation (Richardson and Davis, 1995, p. 144). The results are presented in appendix F.

Abutment scour was computed by use of the Froehlich equation (Richardson and Davis, 1995, p. 48, equation 28). Variables for the Froehlich equation include the Froude number of the flow approaching the embankments, the length of the embankment blocking flow, and the depth of flow approaching the embankment less any roadway overtopping.

The effect of scour on the stone fill embankment material is uncertain so the depth of scour at the wall is unknown. Therefore, the elevation at the toe of the stone fill at the left abutment was used to compute the elevation of scour. The resulting scour elevation for the 100- and 500-year discharges was depicted at the left abutment wall and for the entire embankment in figure 8 . 


\section{Scour Results}

Contraction scour:

Main channel

Live-bed scour

Clear-water scour

Depth to armoring

Left overbank

Right overbank

Local scour:

Abutment scour

Left abutment

Right abutment

Pier scour

Pier 1

Pier 2

Pier 3 100-year discharge
Incipient

500-year overtopping discharge discharge

(Scour depths in feet)

\begin{tabular}{|c|c|c|}
\hline -- & -- & -- \\
\hline 0.0 & 0.0 & 0.0 \\
\hline $0.2^{-}$ & $0.1^{-}$ & $0.2^{-}$ \\
\hline --- & -- $^{-}$ & --' \\
\hline--- & -- & -- \\
\hline
\end{tabular}

11.2

16.2
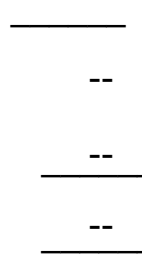

11.7

17.9-
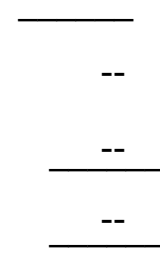

7.9

11.6-

\section{Riprap Sizing}

Abutments:

Left abutment

Right abutment

Piers:

Pier 1

Pier 2

\section{0-year discharge}

\section{5}

1.5
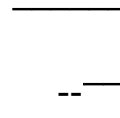

$-$ 


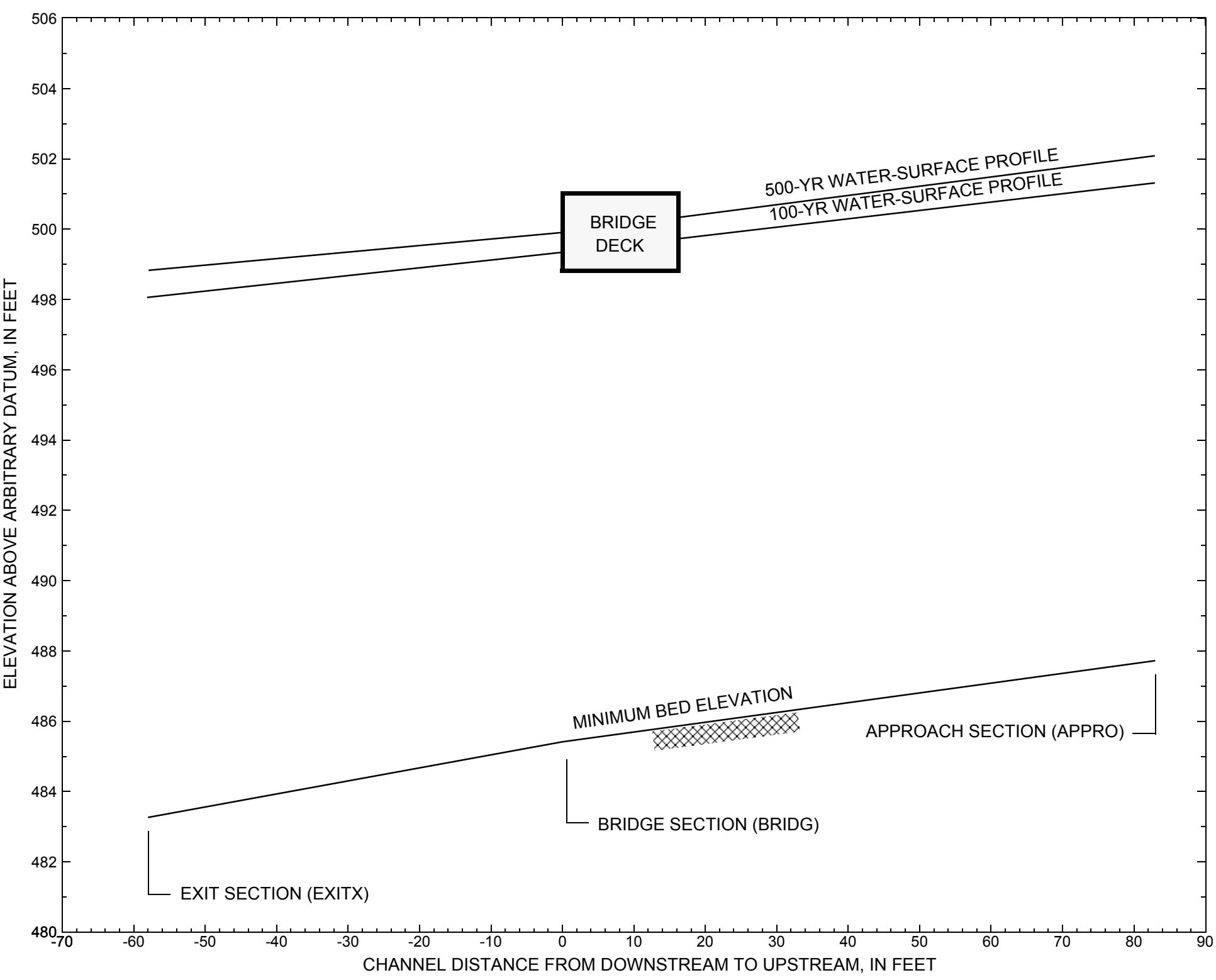

Figure 7. Water-surface profiles for the 100- and 500-year discharges at structure WALLTH00600050 on Town Highway 60, crossing Otter Creek, Wallingford, Vermont. 


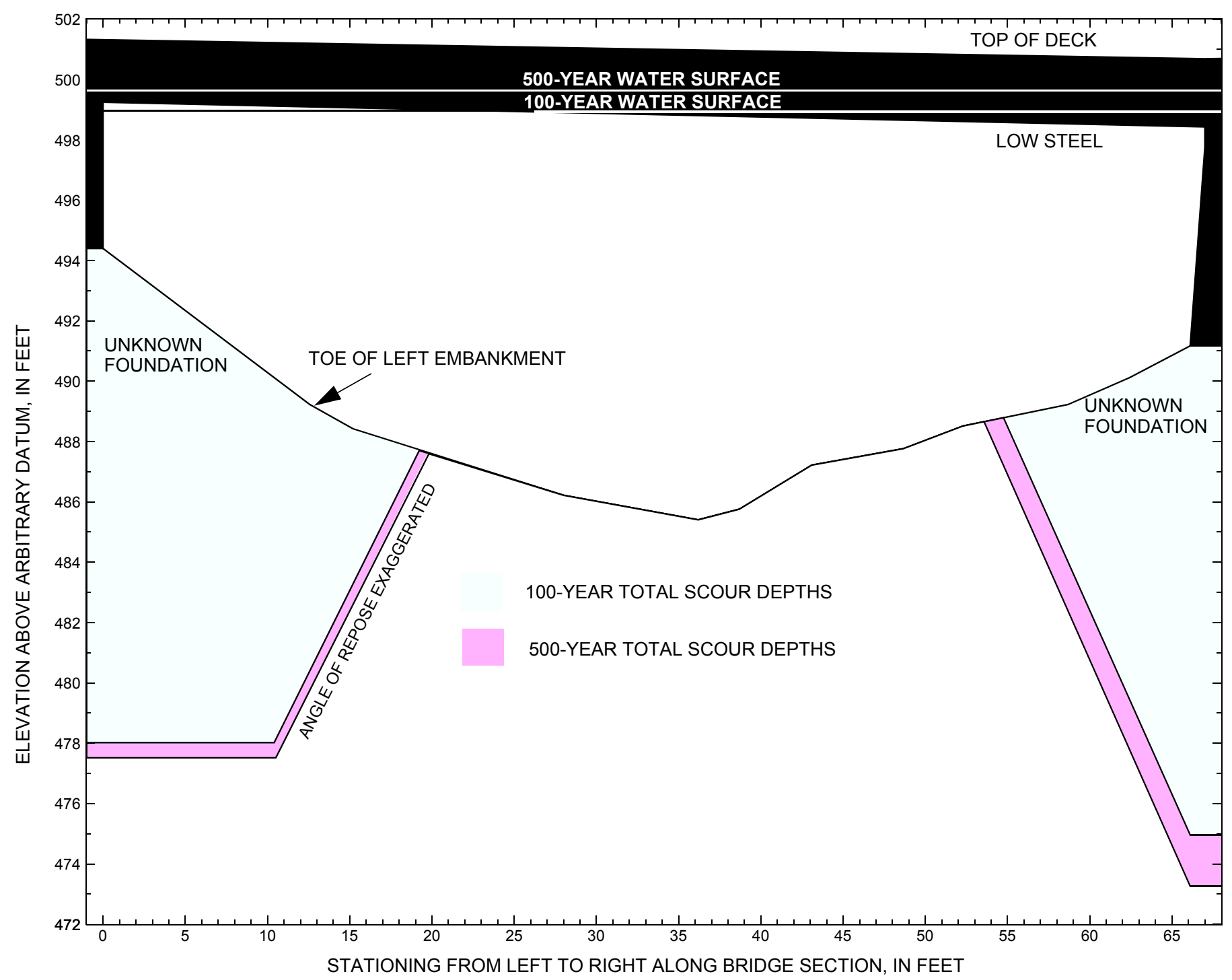

Figure 8. Scour elevations for the 100- and 500-year discharges at structure WALLTH00600050 on Town Highway 60, crossing Otter Creek, Wallingford, Vermont. 
Table 1. Remaining footing/pile depth at abutments for the 100-year discharge at structure WALLTH00600050 on Town Highway 60, crossing Otter Creek, Wallingford, Vermont.

[VTAOT, Vermont Agency of Transportation; --, no data]

\begin{tabular}{|c|c|c|c|c|c|c|c|c|c|c|c|}
\hline Description & Station $^{1}$ & $\begin{array}{l}\text { VTAOT } \\
\text { minimum } \\
\text { low-chord } \\
\text { elevation } \\
\text { (feet) }\end{array}$ & $\begin{array}{l}\text { Surveyed } \\
\text { minimum } \\
\text { low-chord } \\
\text { elevation } \\
\text { (feet) }\end{array}$ & $\begin{array}{c}\text { Bottom of } \\
\text { footing/pile } \\
\text { elevation }{ }^{2} \\
\text { (feet) }\end{array}$ & $\begin{array}{c}\text { Channel } \\
\text { elevation at } \\
\text { abutment/ } \\
\text { pier }^{2} \\
\text { (feet) }\end{array}$ & $\begin{array}{l}\text { Contraction } \\
\text { scour depth } \\
\text { (feet) }\end{array}$ & $\begin{array}{l}\text { Abutment } \\
\text { scour } \\
\text { depth } \\
\text { (feet) }\end{array}$ & $\begin{array}{l}\text { Pier } \\
\text { scour } \\
\text { depth } \\
\text { (feet) }\end{array}$ & $\begin{array}{l}\text { Depth of } \\
\text { total scour } \\
\text { (feet) }\end{array}$ & $\begin{array}{c}\text { Elevation of } \\
\text { scour }^{2} \\
\text { (feet) }\end{array}$ & $\begin{array}{c}\text { Remaining } \\
\text { footing/pile } \\
\text { depth } \\
\text { (feet) }\end{array}$ \\
\hline \multicolumn{12}{|c|}{100 -year discharge is 6,460 cubic-feet per second } \\
\hline Left abutment & 0.0 & -- & 499.2 & -- & 494.4 & 0.0 & -- & -- & -- & 478.0 & -- \\
\hline $\begin{array}{c}\text { Toe of left } \\
\text { embankment }\end{array}$ & 12.6 & -- & -- & -- & 489.2 & 0.0 & 11.2 & -- & 11.2 & 478.0 & -- \\
\hline Right abutment & 67.0 & -- & 498.4 & -- & 491.2 & 0.0 & 16.2 & -- & 16.2 & 475.0 & -- \\
\hline
\end{tabular}

1.Measured along the face of the most constricting side of the bridge.

2.Arbitrary datum for this study.

Table 2. Remaining footing/pile depth at abutments for the 500-year discharge at structure WALLTH00600050 on Town Highway 60, crossing Otter Creek, Wallingford, Vermont.

[VTAOT, Vermont Agency of Transportation; --, no data]

\begin{tabular}{|c|c|c|c|c|c|c|c|c|c|c|c|}
\hline Description & Station ${ }^{1}$ & $\begin{array}{l}\text { VTAOT } \\
\text { minimum } \\
\text { low-chord } \\
\text { elevation } \\
\text { (feet) }\end{array}$ & $\begin{array}{c}\text { Surveyed } \\
\text { minimum } \\
\text { low-chord } \\
\text { elevation } \\
\text { (feet) }\end{array}$ & $\begin{array}{c}\text { Bottom of } \\
\text { footing/pile } \\
\text { elevation }{ }^{2} \\
\text { (feet) }\end{array}$ & $\begin{array}{l}\text { Channel } \\
\text { elevation at } \\
\text { abutment/ } \\
\text { pier }^{2} \\
\text { (feet) }\end{array}$ & $\begin{array}{c}\text { Contraction } \\
\text { scour depth } \\
\text { (feet) }\end{array}$ & $\begin{array}{l}\text { Abutment } \\
\text { scour } \\
\text { depth } \\
\text { (feet) }\end{array}$ & $\begin{array}{l}\text { Pier } \\
\text { scour } \\
\text { depth } \\
\text { (feet) }\end{array}$ & $\begin{array}{l}\text { Depth of } \\
\text { total scour } \\
\text { (feet) }\end{array}$ & $\begin{array}{c}\text { Elevation of } \\
\text { scour }^{2} \\
\text { (feet) }\end{array}$ & $\begin{array}{c}\text { Remaining } \\
\text { footing/pile } \\
\text { depth } \\
\text { (feet) }\end{array}$ \\
\hline \multicolumn{12}{|c|}{500 -year discharge is 7,790 cubic-feet per second } \\
\hline Left abutment & 0.0 & -- & 499.2 & -- & 494.4 & 0.0 & -- & -- & -- & 477.5 & -- \\
\hline $\begin{array}{c}\text { Toe of left } \\
\text { embankment }\end{array}$ & 12.6 & -- & -- & -- & 489.2 & 0.0 & 11.7 & -- & 11.7 & 477.5 & -- \\
\hline Right abutment & 67.0 & -- & 498.4 & -- & 491.2 & 0.0 & 17.9 & -- & 17.9 & 473.3 & -- \\
\hline
\end{tabular}

1.Measured along the face of the most constricting side of the bridge.

2.Arbitrary datum for this study. 


\section{SELECTED REFERENCES}

Arcement, G.J., Jr., and Schneider, V.R., 1989, Guide for selecting Manning's roughness coefficients for natural channels and flood plains:

U.S. Geological Survey Water-Supply Paper 2339, 38 p.

Barnes, H.H., Jr., 1967, Roughness characteristics of natural channels: U.S. Geological Survey Water-Supply Paper 1849,213 p.

Benson, M. A., 1962, Factors Influencing the Occurrence of Floods in a Humid Region of Diverse Terrain: U.S. Geological Survey WaterSupply Paper 1580-B, 64 p.

Brown, S.A. and Clyde, E.S., 1989, Design of riprap revetment: Federal Highway Administration Hydraulic Engineering Circular No. 11, Publication FHWA-IP-89-016, 156 p.

Federal Highway Administration, 1983, Runoff estimates for small watersheds and development of sound design: Federal Highway Administration Report FHWA-RD-77-158.

Federal Highway Administration, 1993, Stream Stability and Scour at Highway Bridges: Participant Workbook: Federal Highway Administration Report FHWA-HI-91-011.

Federal Emergency Management Agency, 1980, Flood Insurance Study, Town of Wallingford, Rutland County, Vermont: Washington, D.C., July 16, 1980.

Froehlich, D.C., 1989, Local scour at bridge abutments in Ports, M.A., ed., Hydraulic Engineering--Proceedings of the 1989 National Conference on Hydraulic Engineering: New York, American Society of Civil Engineers, p. 13-18.

Hayes, D.C.,1993, Site selection and collection of bridge-scour data in Delaware, Maryland, and Virginia: U.S. Geological Survey WaterResources Investigation Report 93-4017, 23 p.

Interagency Advisory Committee on Water Data, 1982, Guidelines for determining flood flow frequency: U.S. Geological Survey, Bulletin 17B of the Hydrology Subcommittee, 190 p.

Johnson, C.G. and Tasker, G.D.,1974, Progress report on flood magnitude and frequency of Vermont streams: U.S. Geological Survey OpenFile Report 74-130, 37 p.

Lagasse, P.F., Schall, J.D., Johnson, F., Richardson, E.V., Chang, F., 1995, Stream Stability at Highway Structures: Federal Highway Administration Hydraulic Engineering Circular No. 20, Publication FHWA-IP-90-014, 144 p.

Laursen, E.M., 1960, Scour at bridge crossings: Journal of the Hydraulics Division, American Society of Civil Engineers, v. 86, no. HY2, p. 39-53.

Potter, W. D., 1957a, Peak rates of runoff in the Adirondack, White Mountains, and Maine woods area, Bureau of Public Roads

Potter, W. D., 1957b, Peak rates of runoff in the New England Hill and Lowland area, Bureau of Public Roads

Richardson, E.V. and Davis, S.R., 1995, Evaluating scour at bridges: Federal Highway Administration Hydraulic Engineering Circular No. 18, Publication FHWA-IP-90-017, 204 p.

Richardson, E.V., Simons, D.B., and Julien, P.Y., 1990, Highways in the river environment: Federal Highway Administration Publication FHWA-HI-90-016.

Ritter, D.F., 1984, Process Geomorphology: W.C. Brown Co., Debuque, Iowa, 603 p.

Shearman, J.O., 1990, User's manual for WSPRO--a computer model for water surface profile computations: Federal Highway Administration Publication FHWA-IP-89-027, 187 p.

Shearman, J.O., Kirby, W.H., Schneider, V.R., and Flippo, H.N., 1986, Bridge waterways analysis model; research report: Federal Highway Administration Publication FHWA-RD-86-108, 112 p.

Talbot, A.N., 1887, The determination of water-way for bridges and culverts.

U.S. Geological Survey, 1986, Wallingford, Vermont 7.5 Minute Series quadrangle map: U.S. Geological Survey Topographic Maps, Scale $1: 24,000$. 


\section{APPENDIX A: \\ WSPRO INPUT FILE}




\section{WSPRO INPUT FILE}

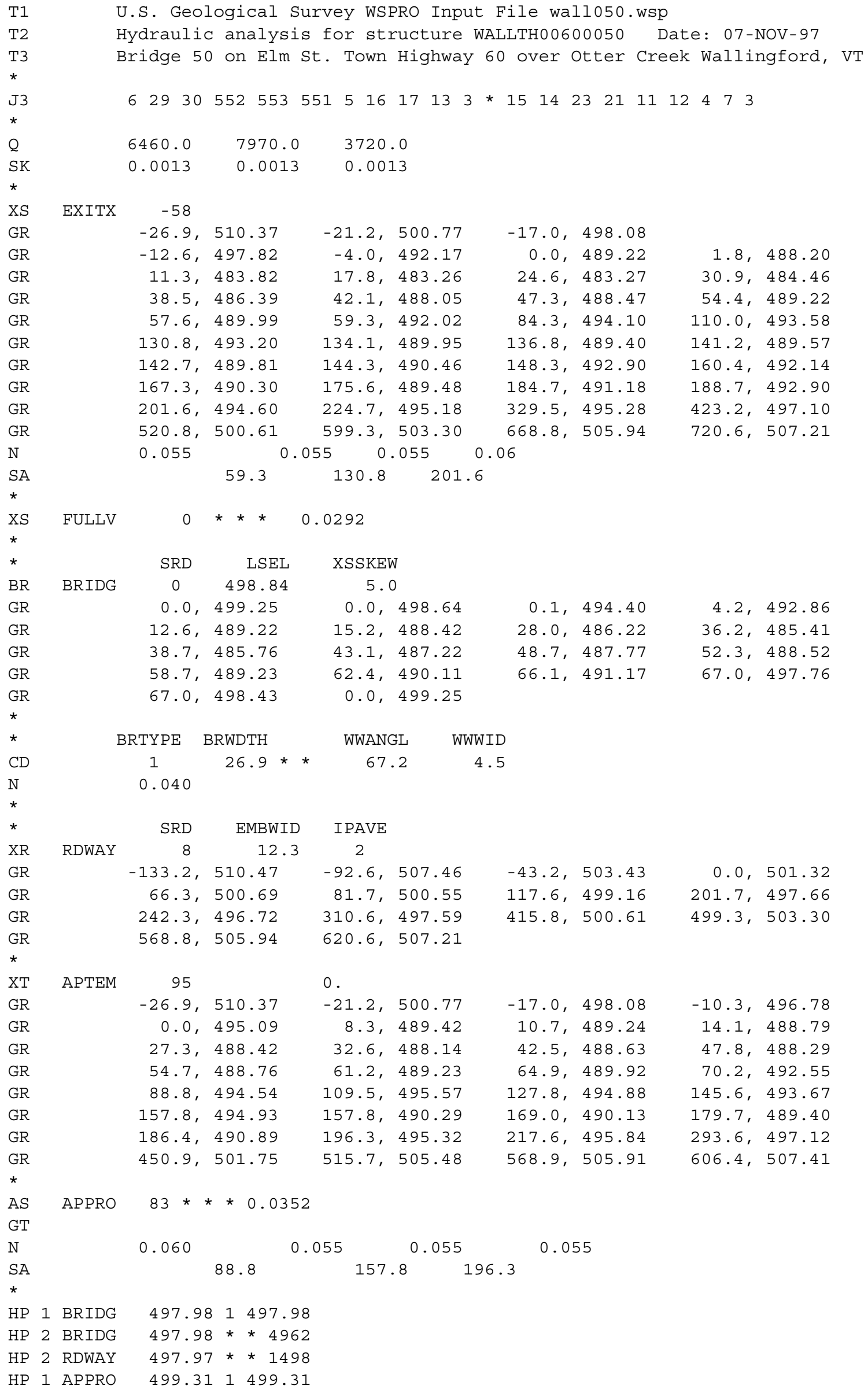




\section{APPENDIX B: \\ WSPRO OUTPUT FILE}




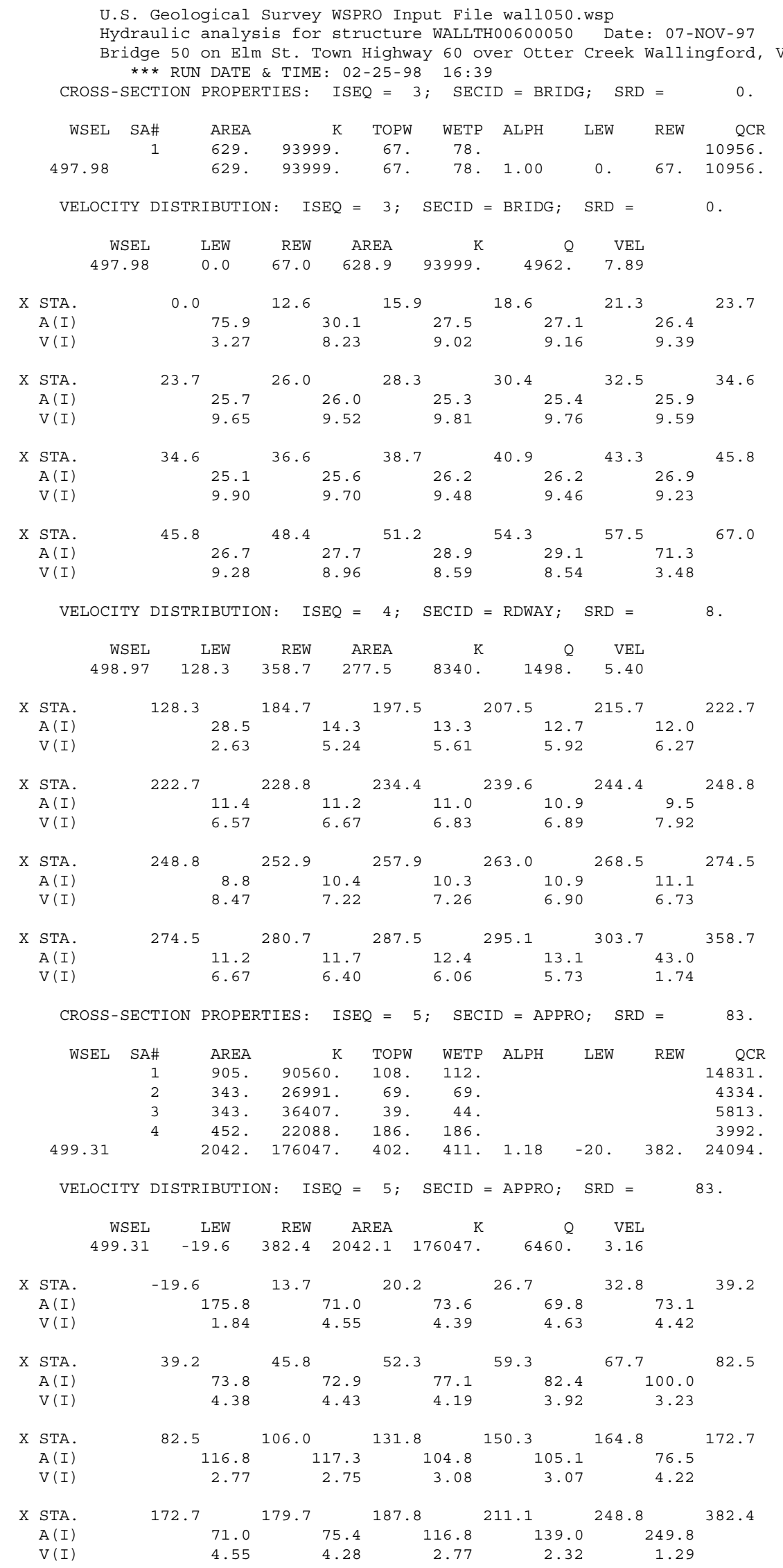




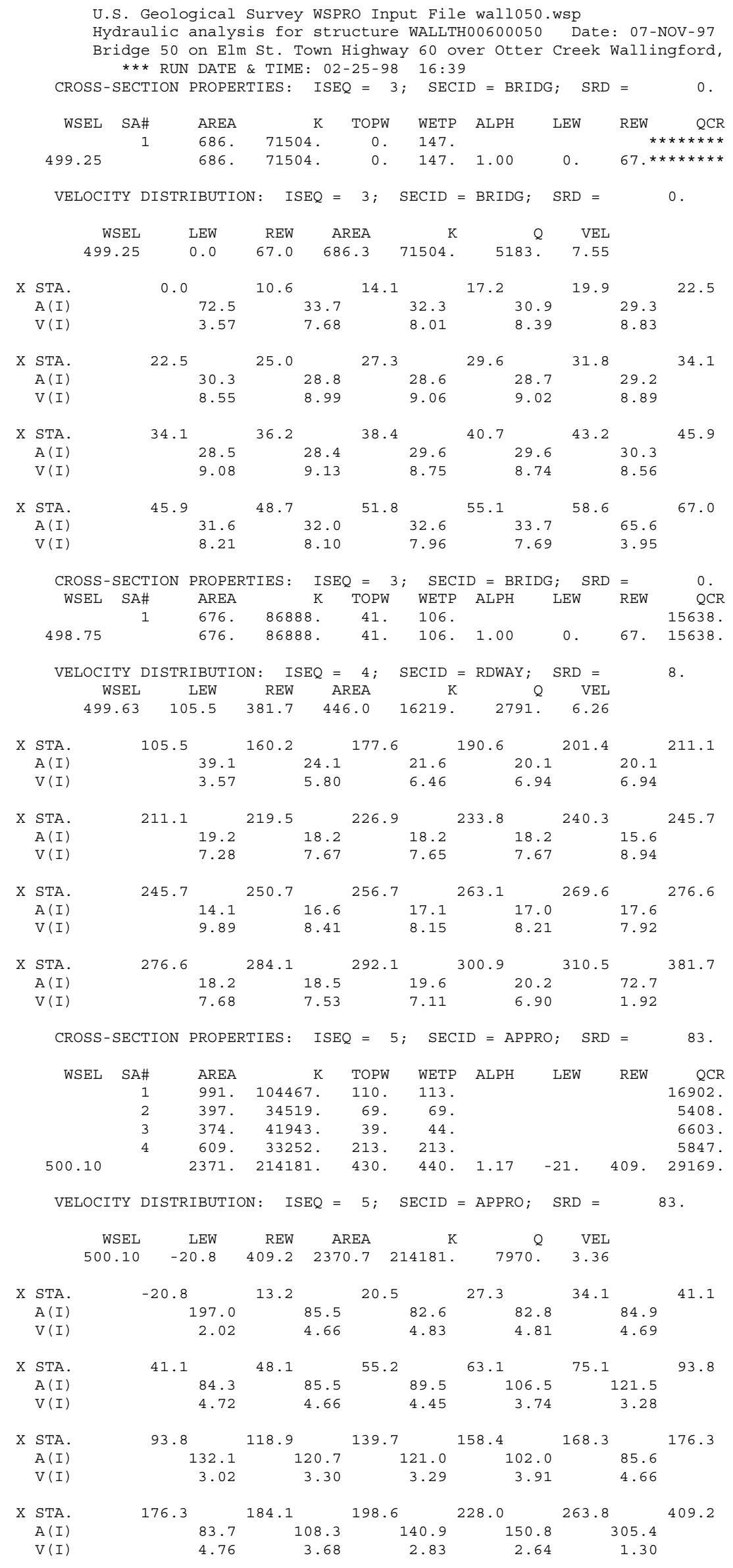


WSPRO OUTPUT FILE (continued)

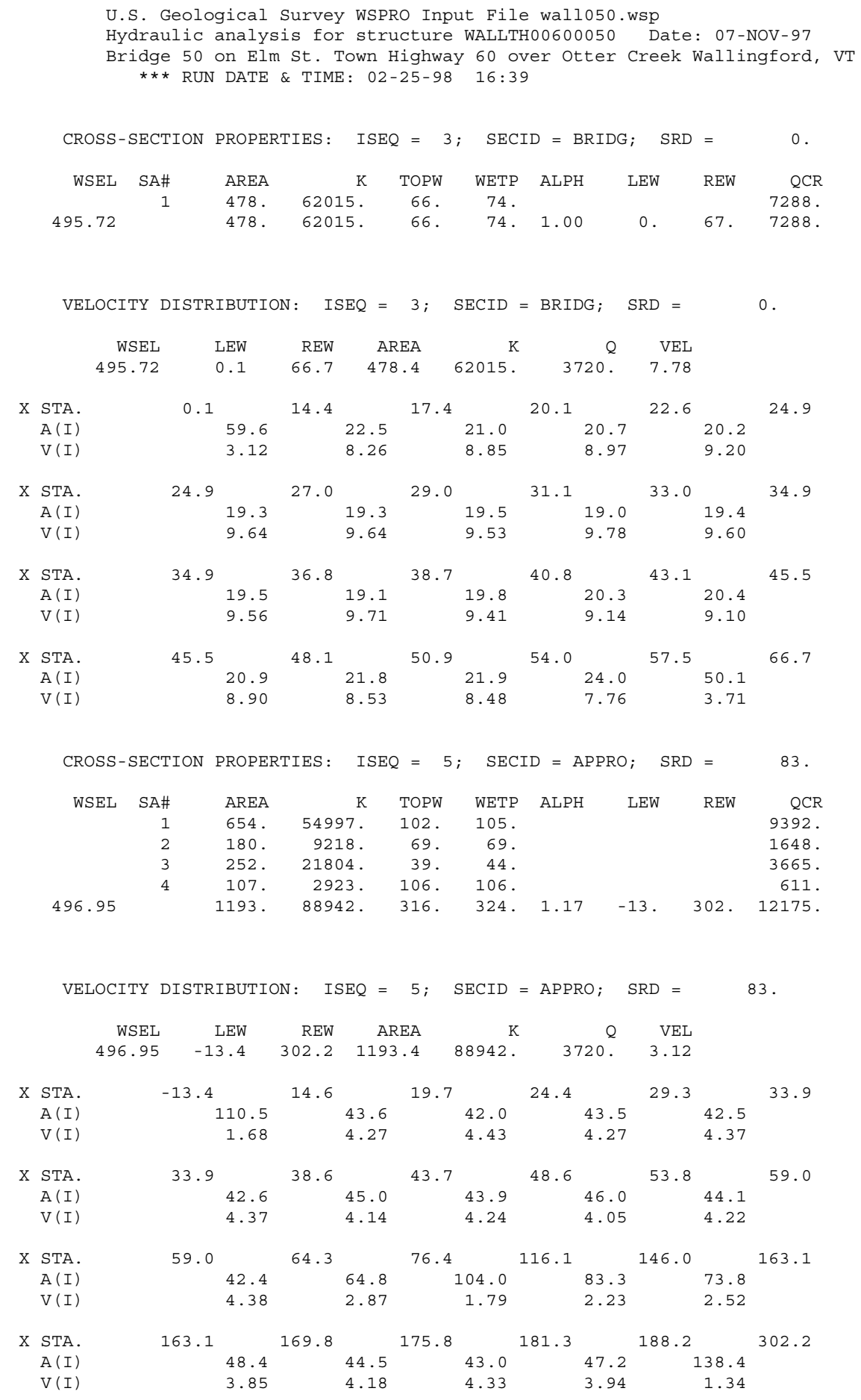


WSPRO OUTPUT FILE (continued)

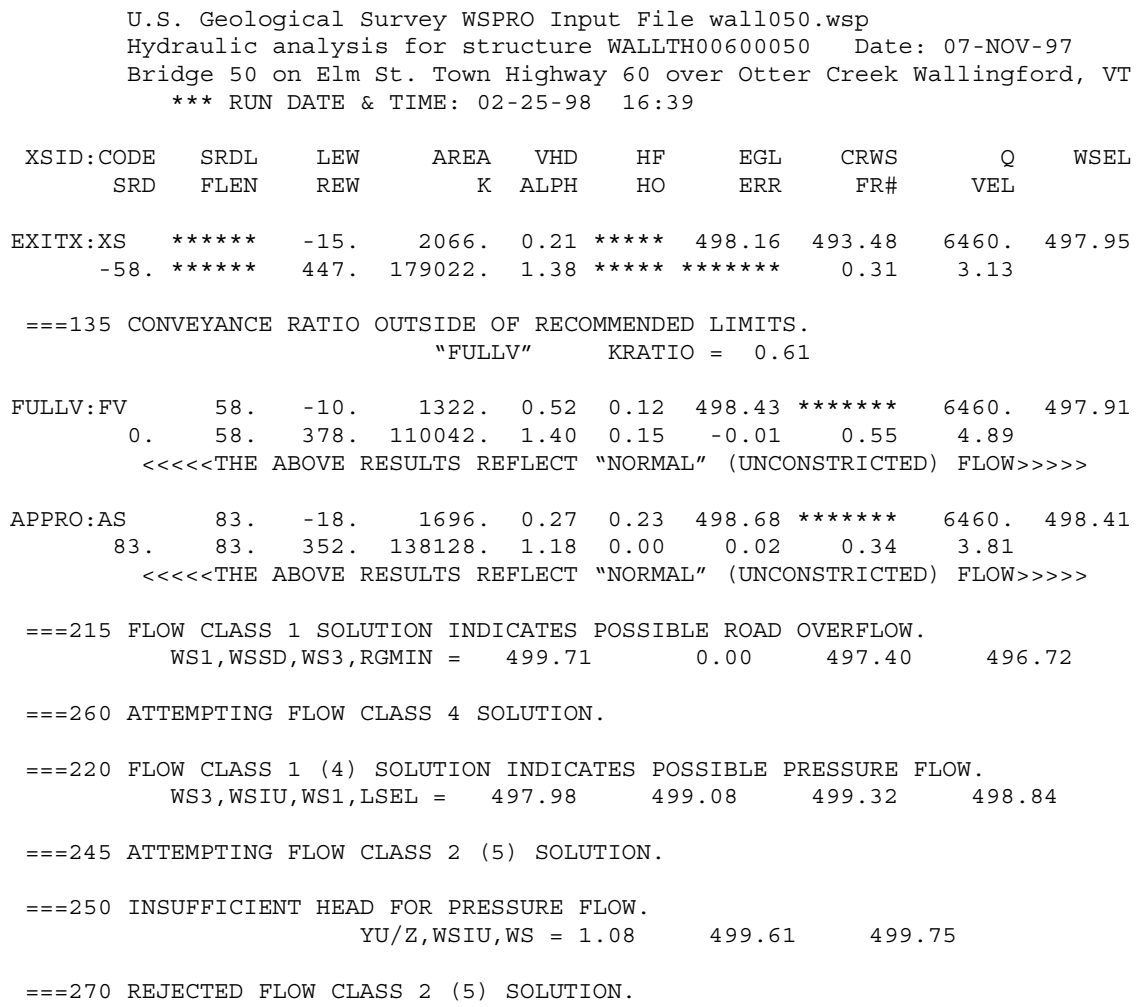


WSPRO OUTPUT FILE (continued)

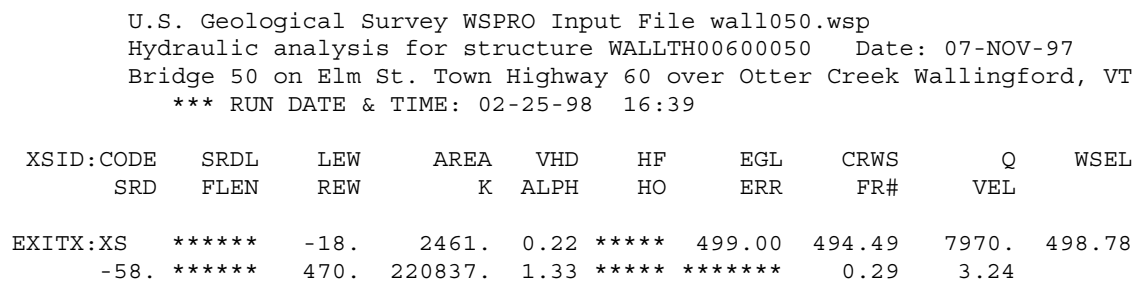

$===135$ CONVEYANCE RATIO OUTSIDE OF RECOMMENDED LIMITS.

$$
\text { "FULLV" KRATIO }=0.64
$$

FULLV : FV 58. $\quad$-11. 1666. $0.51 \quad 0.12 \quad 499.26 * * * * * * * \quad 7970.498 .75$ 0. 58. 421. 140665. 1.42 $0.14 \quad-0.01 \quad 0.51 \quad 4.78$ <<<<THE ABOVE RESULTS REFLECT "NORMAL" (UNCONSTRICTED) FLOW >>>>>

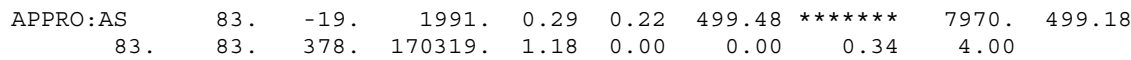
<<<

$==215$ FLOW CLASS 1 SOLUTION INDICATES POSSIBLE ROAD OVERFLOW. $\begin{array}{lllll}\text { WS1,WSSD, WS3 , RGMIN }= & 501.11 & 0.00 & 498.09 & 496.72\end{array}$

$===260$ ATTEMPTING FLOW CLASS 4 SOLUTION.

$==220$ FLOW CLASS 1 (4) SOLUTION INDICATES POSSIBLE PRESSURE FLOW.

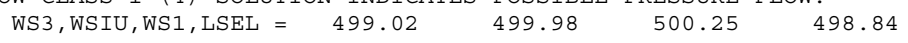

$==245$ ATTEMPTING FLOW CLASS 2 (5) SOLUTION.

$$
<<<<\text { RESULTS REFLECTING THE CONSTRICTED FLOW FOLLOW }>>>>>
$$

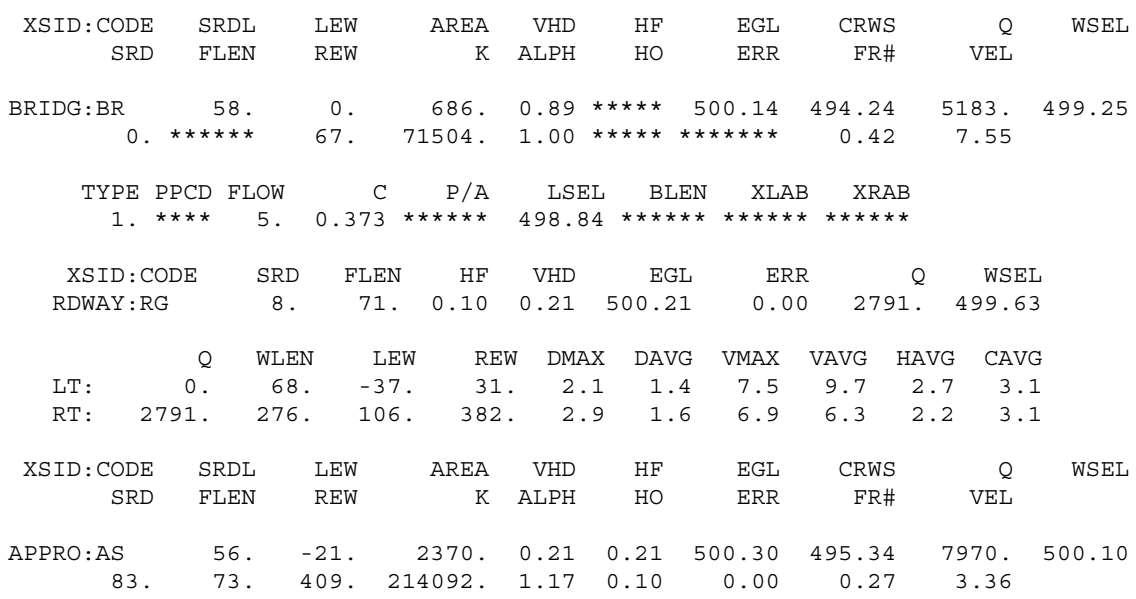

\begin{tabular}{|c|c|c|c|c|c|c|c|c|}
\hline XSID: CODE & SRD & LEW & REW & $Q$ & K & AREA & VEL & WSEL \\
\hline EXITX:XS & -58 & -18. & 470. & 7970. & 220837 . & 2461. & 3.24 & 498.78 \\
\hline FULLV : FV & 0 . & -11 & 421. & 7970. & 140665 . & 1666. & 4.78 & 498.75 \\
\hline BRIDG : BR & 0 . & 0 . & 67. & 5183. & 71504 . & 686. & 7.55 & 499.25 \\
\hline RDWAY : RG & 8. & $* * * *$ & 0 . & 2791. & 0 . & $* \star \star * \star *$ & 2.00 & 499.63 \\
\hline APPRO:AS & 83. & -21. & 409. & 7970. & 214092 . & 2370 . & 3.36 & 500.10 \\
\hline
\end{tabular}

FIRST USER DEFINED TABLE.

SECOND USER DEFINED TABLE.

$\begin{array}{ccrrrrrrrr}\text { XSID : CODE } & \text { CRWS } & \text { FR\# } & \text { YMIN } & \text { YMAX } & \text { HF } & \text { HO } & \text { VHD } & \text { EGL } & \text { WSEL } \\ \text { EXITX:XS } & 494.49 & 0.29 & 483.26 & 510.37 * * * * * * * * * * & 0.22 & 499.00 & 498.78 \\ \text { FULLV:FV } & * * * * * * * * & 0.51 & 484.95 & 512.06 & 0.12 & 0.14 & 0.51 & 499.26 & 498.75 \\ \text { BRIDG: BR } & 494.24 & 0.42 & 485.41 & 499.25 * * * * * * * * * * & 0.89 & 500.14 & 499.25 \\ \text { RDWAY:RG } & * * * * * * * * * * * * * * * & 496.72 & 510.47 & 0.10 * * * * * * & 0.21 & 500.21 & 499.63 \\ \text { APPRO:AS } & 495.34 & 0.27 & 487.72 & 509.95 & 0.21 & 0.10 & 0.21 & 500.30 & 500.10\end{array}$


WSPRO OUTPUT FILE (continued)

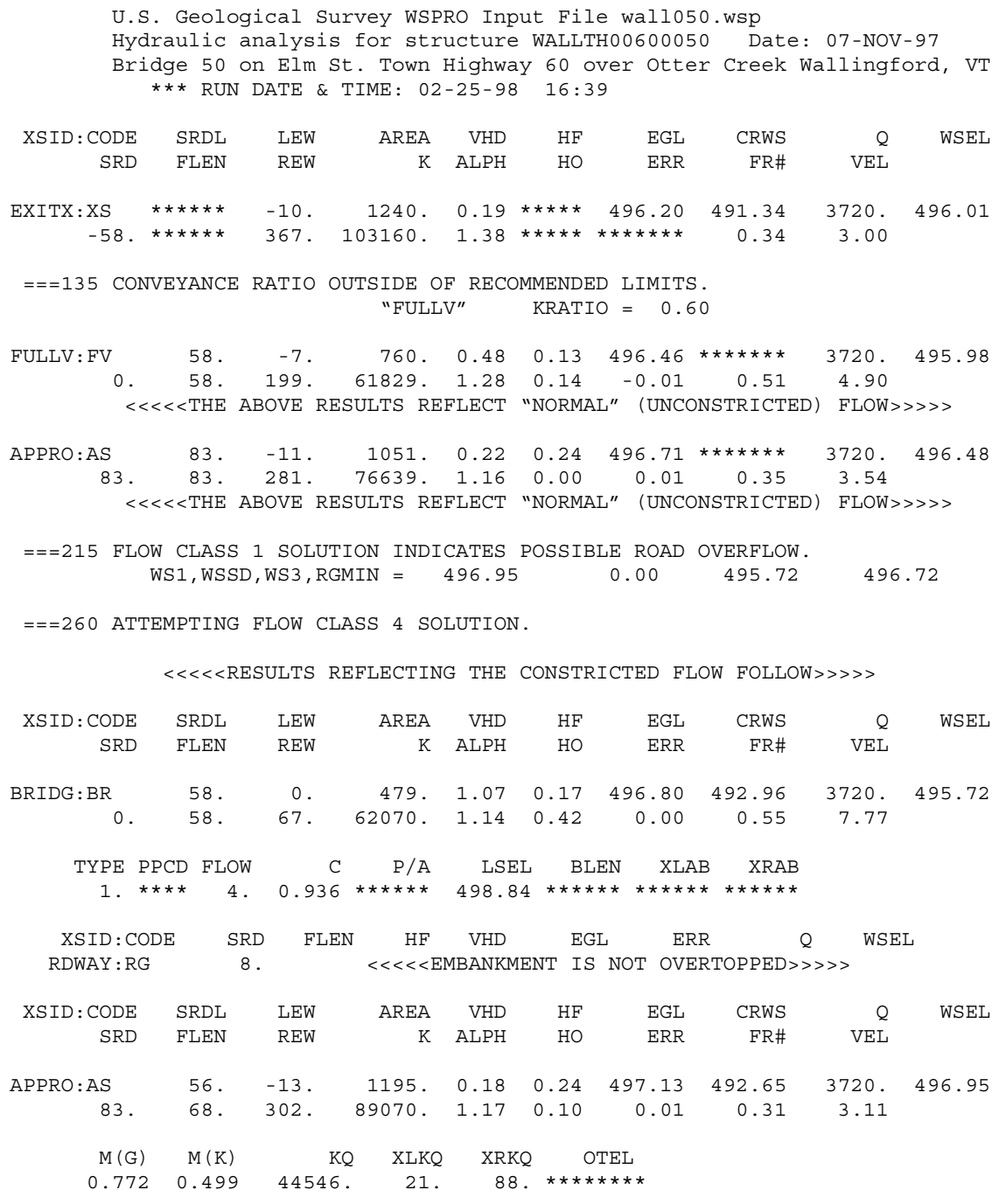

\begin{tabular}{|c|c|c|c|c|c|c|c|c|c|}
\hline XSID : CODE & CRWS & FR\# & YMIN & YMAX & $\mathrm{HF}$ & $\mathrm{HO}$ & VHD & EGL & WSEI \\
\hline EXITX:XS & 491.34 & 0.34 & 483.26 & $510.37 *$ & $* \star * * * *$ & 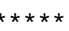 & 0.19 & 496.20 & 496.01 \\
\hline FULLV: FV & $\star * * *$ & 0.51 & 484.95 & 512.06 & 0.13 & 0.14 & 0.48 & 496.46 & 495.98 \\
\hline BR & 492.96 & 0.55 & 485.41 & 499.25 & 0.17 & 0.42 & 1.07 & 496.80 & 495.72 \\
\hline$\therefore: R G$ & $\star \star * \star * * * *$ & $\star * * * *$ & 496.72 & 510.47 & 0.12 * & $\star \star \star \star * *$ & 0.18 & 497.01 & ** \\
\hline PPRO:AS & 492.65 & 0.31 & 487.72 & 509.95 & 0.24 & 0.10 & 0.18 & 497.13 & 496.95 \\
\hline
\end{tabular}




\section{APPENDIX C:}

\section{BED-MATERIAL PARTICLE-SIZE DISTRIBUTION}




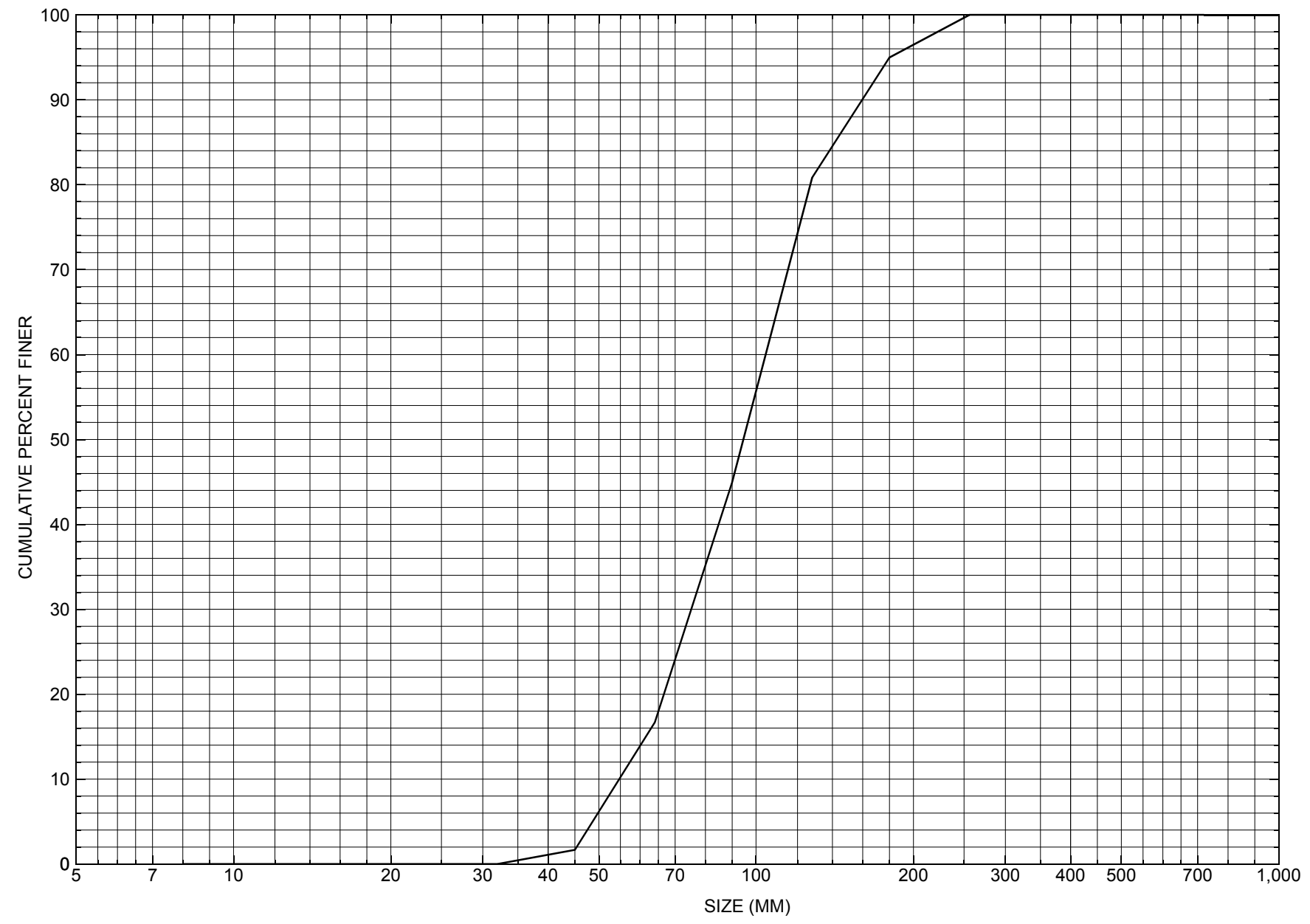

Appendix C. Bed material particle-size distribution for a pebble count in the channel approach of structure WALLTH00600050, in Wallingford, Vermont. 


\section{APPENDIX D: \\ HISTORICAL DATA FORM}




\section{Structure Number WALLTH00600050}

\section{General Location Descriptive}

Data collected by (First Initial, Full last name) $\underline{\mathbf{E}}$. Boehmler

Date $(M M / D D / Y Y) \_\mathbf{0 3} / \underline{22} / \underline{95}$

Highway District Number (I - 2; nn) $\mathbf{0 3}$

Town (FIPS place code; I - 4; nnnnn) $\mathbf{7 5 8 5 0}$

Waterway (I - 6) Otter Creek

Route Number TH060

Topographic Map Wallingford

Latitude (I - 16; nnnn.n) $\mathbf{4 3 2 8 4}$
County (FIPS county code; I - 3; nnn)

Mile marker (I - 11; nnn.nnn) $\mathbf{0 0 0 0 0 0}$

Road Name ( $(I)$ - : Elm Street

Vicinity (I - 9) $\mathbf{0 . 1}$ mile to jet with Creek Rd

Hydrologic Unit Code: $\mathbf{0 2 0 1 0 0 0 2}$

Longitude (i - 17; nnnnn.n) $\mathbf{7 2 5 8 8}$

\section{Select Federal Inventory Codes}

FHWA Structure Number $(I$ - 8) $\mathbf{1 0 1 1 2 5 0 0 5 0 1 1 2 5}$

Maintenance responsibility $(I-21 ; n n) \quad \mathbf{0 3}$

Year built (I - 27; YYYY) 1919

Average daily traffic, ADT (I - 29; nnnnnn) 000030

Year of ADT (I - 30; YY) $\mathbf{9 2}$

Opening skew to Roadway $(I-34 ; n n) \quad \mathbf{0 0}$

Operational status $(I-41 ; X) \mathbf{P}$

Structure type (I - 43; nnn) $\mathbf{3 1 0}$

Approach span structure type $(I-44 ; n n n)$ 000

Number of spans (I - 45; nnn) $\underline{\mathbf{0 0 1}}$

Number of approach spans (I - 46; nnnn) $\mathbf{0 0 0 0}$

Comments:

The structural inspection report of 10/3/94 indicates the structure is a steel (pony) thru-truss type bridge with a timber deck. The abutment walls and wingwalls are "laid-up" stone. There is no wingwall on the one downstream end of the right abutment. The face of the right abutment wall has a random vertical settlement crack at the centerline of the bridge. Originally, the report indicates there was a concrete footing along the bottom of the right abutment and its wingwall. However, most of the concrete of the footing has spalled off, with deep voided sections along the bottom. Its one wingwall is broken into three distinct sections reportedly, and settlement has been a problem. The left abutment has a few random fine cracks and small leaks indicated. (Continued, page 33)
Maximum span length (I - 48; nnnn) $\underline{\mathbf{0 0 7 0}}$

Structure length (I - 49; nnnnnn) $\underline{\mathbf{0 0 0 0 7 2}}$

Deck Width (I - 52; nn.n) 123

Channel \& Protection $(I-61 ; n) \underline{5}$

Waterway adequacy $(I-71 ; n)$

Underwater Inspection Frequency $(I-92 B ; X Y Y) \_$N

Year Reconstructed (I - 106) $\mathbf{0 0 0 0}$

Clear span (nnn.n ft)

Vertical clearance from streambed (nnn.n ft) $\underline{\mathbf{0 1 0 . 6}}$

Waterway of full opening $\left(n n n . n \mathrm{ft}^{2}\right)$ 


\section{Bridge Hydrologic Data}

Is there hydrologic data available? $\underline{\mathbf{Y}}$ if No, type ctrl- $n$ h VTAOT Drainage area $\left(m i^{2}\right): \underline{\mathbf{1 0 2 . 0}}$

Terrain character:

Stream character \& type: -

Streambed material:

Discharge Data (cfs):

$$
\mathrm{Q}_{2.33} \frac{-}{\mathbf{1 2 5 0 0}}
$$

$\mathrm{Q}_{10} \frac{\mathbf{7 0 0 0}}{\mathbf{1 4 5 0 0}}$

$\mathrm{Q}_{25} \frac{\mathbf{1 0 0 0 0}}{\mathrm{Q}_{500}-}$

Record flood date (MM / DD / YY): l

Water surface elevation $(f t):-$

Estimated Discharge (cfs): Velocity at $\mathrm{Q}$ $(\mathrm{ft} / \mathrm{s}):$

Ice conditions (Heavy, Moderate, Light) : Debris (Heavy, Moderate, Light):

The stage increases to maximum highwater elevation (Rapidly, Not rapidly):

The stream response is (Flashy, Not flashy):

Describe any significant site conditions upstream or downstream that may influence the stream's stage: The channel of Otter Creek here divides into two parts. This bridge is reportedly over the main channel during lower flows. The other bridge serves as an overflow structure, which is mainly active during high discharge periods.

Watershed storage area (in percent):

The watershed storage area is: - (1-mainly at the headwaters; 2- uniformly distributed; 3-immediatly upstream oi the site)

Water Surface Elevation Estimates for Existing Structure:

\begin{tabular}{|l|l|l|l|l|l|}
\hline Peak discharge frequency & $Q_{2.33}$ & $Q_{10}$ & $Q_{25}$ & $Q_{50}$ & $Q_{100}$ \\
Water surface elevation (ft)) & - & $\mathbf{9 . 1}$ & $\mathbf{1 1 . 7}$ & $\mathbf{1 3 . 2}$ & $\mathbf{1 4 . 0}$ \\
Velocity $(\mathrm{ft} / \mathrm{sec})$ & - & - & - & - & - \\
\hline
\end{tabular}

Long term stream bed changes: -

Is the roadway overtopped below the $\mathrm{Q}_{100}$ ? (Yes, No, Unknown): $\mathbf{U} \quad$ Frequency: -

Relief Elevation $(f t)$ :

Discharge over roadway at $\mathrm{Q}_{100}\left(f^{3} / \mathrm{sec}\right)$ : -

Are there other structures nearby? (Yes, No, Unknown): $\mathbf{U}$ Upstream distance (miles): Town: If No or Unknown, type ctrl-n os Highway No. : Structure No. : Year Built:

Clear span (ft): Clear Height (ft): Full Waterway $\left(f t^{2}\right)$ : 
Downstream distance (miles): Town: Year Built:

Highway No. : Structure No. : Structure Type:

Clear span $(f t):$ Clear Height $(f t)$ :

Full Waterway $\left(f^{2}\right)$ :

Comments:

Additionally, a vertical crack has developed in the wall near the centerline of the bridge. Some boulder fill is noted in front of each abutment and there is some stone fill on the streambanks up- and downstream on the left abutment side of the channel. Gravel bars and debris accumulation problems are noted as minor. The hydraulics section folder on this bridge had very little information available.

\section{USGS Watershed Data}

Watershed Hydrographic Data

Drainage area $(D A) \underline{\mathbf{1 0 2 . 6 0}} \mathrm{mi}^{2}$ Lake/pond/swamp area 0.78 $\mathrm{mi}^{2}$

Watershed storage (ST) 0.8

Bridge site elevation 571 $\mathrm{ft}$ $\%$

Main channel length 21.349 $\mathrm{mi}$

$10 \%$ channel length elevation $\mathbf{5 7 1}$ $\mathrm{ft} \quad 85 \%$ channel length elevation 835 $\mathrm{ft}$

Main channel slope $(S)$

(S) 16.49 $\mathrm{ft} / \mathrm{mi}$

Watershed Precipitation Data

Average site precipitation in Average headwater precipitation in

Maximum 2yr-24hr precipitation event $(124,2)$ in

Average seasonal snowfall (Sn) $\mathrm{ft}$ 


\section{Bridge Plan Data}

Are plans available? $\mathbf{N} \quad$ If no, type ctrl-n $p l \quad$ Date issued for construction $(M M / Y Y Y Y):-$

Project Number

Minimum channel bed elevation:

Low superstructure elevation: USLAB DSLAB USRAB DSRAB Benchmark location description:

NO BENCHMARK INFORMATION

Reference Point (MSL, Arbitrary, Other): Datum (NAD27, NAD83, Other):

Foundation Type: 4

If 1: Footing Thickness

If 2: Pile Type:

If 3: Footing bottom elevation:

Is boring information available? $\mathbf{N}$

Foundation Material Type: 3

(1-Spreadfooting; 2-Pile; 3- Gravity; 4-Unknown)

Footing bottom elevation: -

Briefly describe material at foundation bottom elevation or around piles:

NO FOUNDATION MATERIAL INFORMATION

Comments:

NO PLANS. 


\section{Cross-sectional Data}

Is cross-sectional data available? Yes If no, type ctrl-n xs

Source (FEMA, VTAOT, Other)? FEMA

Comments:

This cross section is taken from a HEC-2 input file.

\begin{tabular}{|l|l|l|l|l|l|l|l|l|l|l|l|}
\hline Station & 124 & 134 & 146 & 159 & 171 & 195 & - & - & - & - & - \\
\hline Feature & LAB & - & - & - & - & RAB & - & - & - & - & - \\
\hline $\begin{array}{l}\text { Low chord } \\
\text { elevation }\end{array}$ & 565 & 565 & 565 & 565 & 565 & 565 & - & - & - & - & - \\
\hline $\begin{array}{l}\text { Bed } \\
\text { elevation }\end{array}$ & 561 & 555.3 & 553.5 & 552 & 553 & 557.8 & - & - & - & - & - \\
\hline $\begin{array}{l}\text { Low chord } \\
\text { to bed }\end{array}$ & 4 & 9.7 & 11.5 & 13 & 12 & 7.2 & - & - & - & - & - \\
\hline Station & - & - & - & - & - & - & - & - & - & - & - \\
\hline Feature & - & - & - & - & - & - & - & - & - & - & - \\
\hline $\begin{array}{l}\text { Low chord } \\
\text { elevation }\end{array}$ & - & - & - & - & - & - & - & - & - & - & - \\
\hline $\begin{array}{l}\text { Bed } \\
\text { elevation }\end{array}$ & - & - & - & - & - & - & - & - & - & - & - \\
\hline $\begin{array}{l}\text { Low chord } \\
\text { to bed }\end{array}$ & - & - & - & - & - & - & - & - & - & - & - \\
\hline
\end{tabular}

Source (FEMA, VTAOT, Other)?

Comments: -

\begin{tabular}{|l|l|l|l|l|l|l|l|l|l|l|l|}
\hline Station & - & - & - & - & - & - & - & - & - & - & - \\
\hline Feature & - & - & - & - & - & - & - & - & - & - & - \\
\hline $\begin{array}{l}\text { Low chord } \\
\text { elevation }\end{array}$ & - & - & - & - & - & - & - & - & - & - & - \\
\hline $\begin{array}{l}\text { Bed } \\
\text { elevation }\end{array}$ & - & - & - & - & - & - & - & - & - & - & - \\
\hline $\begin{array}{l}\text { Low chord } \\
\text { to bed }\end{array}$ & - & - & - & - & - & - & - & - & - & - & - \\
\hline Station & - & - & - & - & - & - & - & - & - & - & - \\
\hline Feature & - & - & - & - & - & - & - & - & - & - & - \\
\hline $\begin{array}{l}\text { Low chord } \\
\text { elevation }\end{array}$ & - & - & - & - & - & - & - & - & - & - & - \\
\hline $\begin{array}{l}\text { Bed } \\
\text { elevation }\end{array}$ & - & - & - & - & - & - & - & - & - & - & - \\
\hline $\begin{array}{l}\text { Low chord } \\
\text { to bed }\end{array}$ & - & - & - & - & - & - & - & - & - & - & - \\
\hline
\end{tabular}




\section{APPENDIX E: \\ LEVEL I DATA FORM}


U. S. Geological Survey

Bridge Field Data Collection and Processing Form

Qa/Qc Check by: CG Date: $\underline{02 / 21 / 96}$

\section{Structure Number WALLTH00600050}

\section{A. General Location Descriptive}

1. Data collected by (First Initial, Full last name) M. Ivanoff

2. Highway District Number $\mathbf{0 3}$

County Rutland (021)

Mile marker $\mathbf{0}$

Waterway $(I-6)$ Otter Creek

Town Wallingford (75850)

Route Number TH 60

Road Name EIm Street

. Descriptive comments:

Hydrologic Unit Code: 02010002

The site is located 0.1 mile from the junction of EIm Street with Creek Road.

\section{B. Bridge Deck Observations}
4. Surface cover... LBUS 6
RBUS 6
LBDS 6
RBDS 6
Overall 6

(2b us,ds,lb,rb: 1- Urban; 2- Suburban; 3- Row crops; 4- Pasture; 5- Shrub- and brushland; 6- Forest; 7- Wetland)
5. Ambient water surface... US 1
UB 1
DS 1
(1- pool; 2- riffle)

6. Bridge structure type 1 (1- single span; 2- multiple span; 3- single arch; 4- multiple arch; 5- cylindrical culvert; 6- box culvert; or 7- other)
7. Bridge length $\mathbf{7 2 . 0}$
(feet)
Span length $\mathbf{7 0 . 0}$
(feet)
Bridge width 12.3 (feet)

\section{Road approach to bridge:}

\section{LB 2 RB 1 ( 0 even, 1- lower, 2- higher) \\ 9. LB 2 RB $\underline{2}$ (1-Paved, 2- Not paved)}

10. Embankment slope (run / rise in feet / foot)

US left

\begin{tabular}{|c|c|c|c|}
\hline \multicolumn{2}{|c|}{ Protection } & \multirow{2}{*}{ 13.Erosion } & 14.Severity \\
\hline 11.Type & 12.Cond. & & \\
\hline $\mathbf{5}$ & $\mathbf{1}$ & $\mathbf{2}$ & $\mathbf{1}$ \\
\hline
\end{tabular}

LBUS

RBUS

RBDS

LBDS

\begin{tabular}{l|l|l}
5 & $\frac{1}{5}$ & $\frac{1}{5}$ \\
\hline 5 & $\frac{1}{1}$ & \\
\hline
\end{tabular}

\begin{tabular}{l}
2 \\
\hline 2 \\
\hline 0 \\
\hline
\end{tabular}

1

1

$\mathbf{0}$

Bank protection types: 0- none; 1- $<12$ inches; 2- < 36 inches; 3- $<48$ inches;

4- < 60 inches; 5- wall / artificial levee

Bank protection conditions: 1- good; 2- slumped;

3- eroded; 4- failed

Erosion: 0 - none; 1- channel erosion; 2 -

road wash; 3- both; 4- other

Erosion Severity: 0 - none; 1- slight; 2- moderate; 3- severe

\section{Channel approach to bridge (BF):}

15. Angle of approach: $\mathbf{2 5}$

16. Bridge skew: $\mathbf{2 5}$

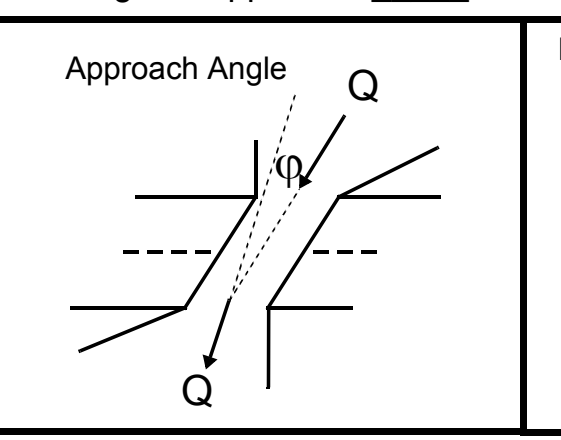

17. Channel impact zone 1 :

Where? LB (LB, RB)

Range? 40 feet US

Channel impact zone 2:

Where? RB (LB, RB) Bridge Skew Angle

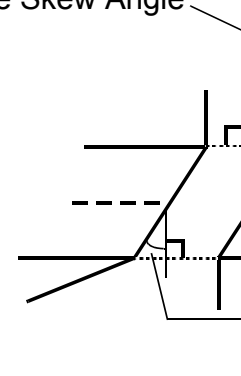

\section{Exist? $\mathbf{Y}(Y$ or $N)$}

Severity 1

$U B, D S)$ to $\mathbf{0}$ feet DS

Opening skew to roadway

$\alpha=\mathbf{5 . 0}$ 
18. Bridge Type: 1a

1a- Vertical abutments with wingwalls

$1 \mathrm{~b}$ - Vertical abutments without wingwalls

2- Vertical abutments and wingwalls, sloping embankment Wingwalls parallel to abut. face

3- Spill through abutments

4- Sloping embankment, vertical wingwalls and abutments

Wingwall angle less than $90^{\circ}$.

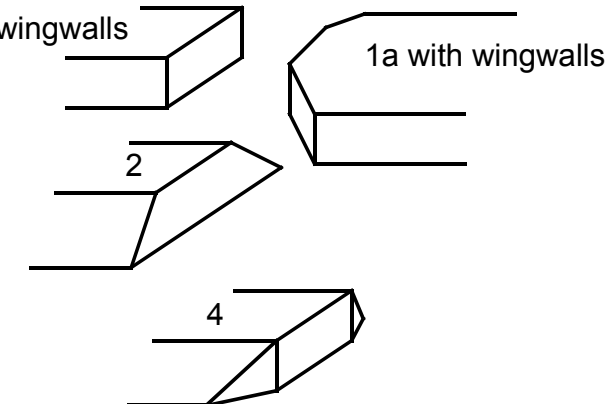

19. Bridge Deck Comments (surface cover variations, measured bridge and span lengths, bridge type variations, approach overflow width, etc.)

7. The bridge dimension values are from the VTAOT database. The measured bridge length is $72 \mathrm{ft}$, span length is $68.5 \mathrm{ft}$, and bridge width is $12 \mathrm{ft}$.

11. Wood cribbing is in place along both sides of the road approaches.

17. Impact zone 2 is along the channel and at high flow impacts the road approach embankment.

\section{Upstream Channel Assessment}

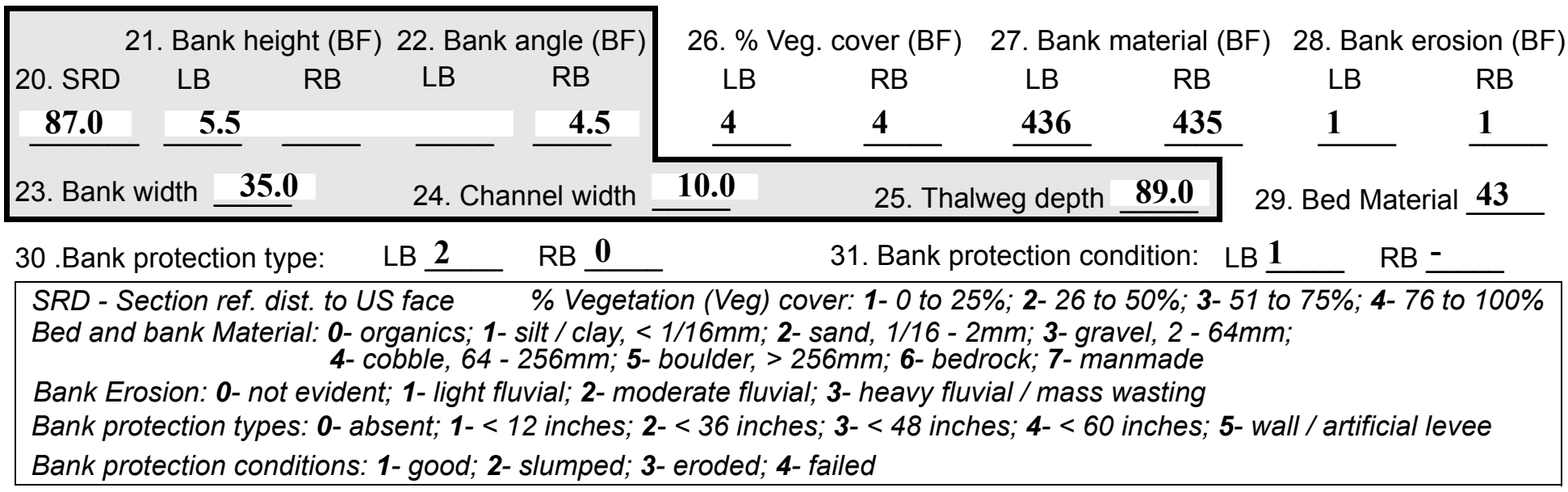

32. Comments (bank material variation, minor inflows, protection extent, etc.):

27. The left bank material consists of cobbles and gravel. There is bedrock underneath the cobbles and gravel. This bedrock extends $200 \mathrm{ft}$ upstream and along the high left embankment. The right bank is made up of cobbles and gravel with some boulders. The boulders may have been placed, as the structural inspection of 1994 noted stones along the up- and downstream banks.

29. The bed material consists of cobbles and gravel.

30. The left bank protection extends $20 \mathrm{ft}$ upstream from the bridge face. 
36. Point bar extent: 100 feet $\underline{\mathbf{U S}}$ (US, UB) to $\underline{\mathbf{2 0 0}}$ feet $\underline{\mathrm{US}}$ (US, UB, DS) positioned $\underline{\mathbf{0}} \%$ LB to $\underline{\mathbf{7 0}} \%$ RB

37. Material: 43

38. Point or side bar comments (Circle Point or Side, Note additional bars, material variation, status, etc.):

This side bar consists of cobbles and gravel.

Another bar has formed mid-channel from $240 \mathrm{ft}$ to $350 \mathrm{ft}$ upstream with a mid-bar width of $50 \mathrm{ft}$. It is vegetated with $30 \mathrm{ft}$ tall trees.

39. Is a cut-bank present? $\underline{\mathbf{Y}}$ (Y or if $N$ type $c t r-n c b)$

40. Where? LB (LB or RB)

41. Mid-bank distance: $\mathbf{4 0}$

42. Cut bank extent: 90

43. Bank damage: 1

(1- eroded and/or creep; 2- slip failure; 3- block failure)

44. Cut bank comments (eg. additional cut banks, protection condition, etc.):

This is a steepened bank $4 \mathrm{ft}$ above the edge of water exposing some roots.

45. Is channel scour present? $\mathbf{Y}$ (Y or if $N$ type ctrl-n cs)

47. Scour dimensions: Length $\mathbf{4 0}$

Width 25

Depth : 4

46. Mid-scour distance: 230

48. Scour comments (eg. additional scour areas, local scouring process, etc.):

At $220 \mathrm{ft}$ upstream bedrock lines the left channel bank to the bed with a $4 \mathrm{ft}$ deep pool. Bedrock is exposed at the base of the pool.

49. Are there major confluences? $\mathbf{N}$ ( $Y$ or if $N$ type ctrl-n $m c$ )

51. Confluence 1: Distance Confluence 2: Distance 52. Enters on Enters on ( $L B$ or $R B$ ) ( $L B$ or $R B)$

54. Confluence comments (eg. confluence name):

NO MAJOR CONFLUENCES

Roaring brook enters on the right bank $350 \mathrm{ft}$ upstream.
50. How many? -

53. Type(1-perennial; 2- ephemeral)

Type (1- perennial; 2- ephemeral)

\section{Under Bridge Channel Assessment}

55. Channel restraint (BF)? LB 2

\begin{tabular}{|ccccc|}
\hline \multicolumn{2}{|c}{ 56. Height (BF) } & \multicolumn{3}{c}{57 Angle (BF) } \\
LB & RB & LB & RB \\
$\mathbf{5 6 . 5}$ & & & $\mathbf{1 . 0}$ & \\
\hline
\end{tabular}

58. Bank width (BF) -

59. Channel width (1- natural bank; 2- abutment; 3- artificial levee)

Bed and bank Material: 0- organics; 1- silt / clay, < 1/16mm; 2- sand, 1/16 - 2mm; 3- gravel, 2 - 64mm; 4- cobble, 64 - 256mm; 5- boulder, > 256mm; 6- bedrock; 7- manmade

Bank Erosion: 0- not evident; 1- light fluvial; 2- moderate fluvial; 3- heavy fluvial / mass wasting

64. Comments (bank material variation, minor inflows, protection extent, etc.):

547

The right abutment has a mix of boulders and rough concrete blocks extending into the channel. 
65. Debris and Ice Is there debris accumulation?

(Yor $N)$ 66. Where? $\underline{Y}$

(1- Upstream; 2- At bridge; 3- Both)

67. Debris Potential 1 (1-Low; 2-Moderate; 3- High)

68. Capture Efficiency 2

(1-Low; 2- Moderate; 3- High)

69. Is there evidence of ice build-up? 1 ( $Y$ or $N)$

Ice Blockage Potential $\underline{\mathbf{N}}$

(1- Low; 2- Moderate; 3- High)

70. Debris and Ice Comments:

1

Debris has accumulated along the right bank up to the road approach. There are trees leaning over the upstream channel.

\begin{tabular}{|l|c|c|c|c|c|c|c|c|}
\hline Abutments & $\begin{array}{c}\text { 71. Attack } \\
\angle \text { (BF) }\end{array}$ & $\begin{array}{c}72 \text {. Slope } \angle \\
\text { (Qmax) }\end{array}$ & $\begin{array}{c}\text { 73. Toe } \\
\text { loc. (BF) }\end{array}$ & $\begin{array}{c}\text { 74. Scour } \\
\text { Condition }\end{array}$ & $\begin{array}{c}75 . \text { Scour } \\
\text { depth }\end{array}$ & $\begin{array}{c}\text { 76. Exposure } \\
\text { depth }\end{array}$ & 77. Material & 78. Length \\
\hline LABUT & & $\mathbf{2 5}$ & $\mathbf{9 0}$ & $\mathbf{2}$ & $\mathbf{0}$ & $\mathbf{0}$ & $\mathbf{0}$ & $\mathbf{9 0 . 0}$ \\
\hline RABUT & $\mathbf{1}$ & $\mathbf{0}$ & $\mathbf{8 0}$ & & & $\mathbf{2}$ & $\mathbf{3}$ & $\mathbf{6 6 . 5}$ \\
\hline
\end{tabular}

Pushed: $L B$ or RB

Toe Location (Loc.): 0- even, 1- set back, 2- protrudes

Scour cond.: 0- not evident; 1- evident (comment); 2- footing exposed; 3-undermined footing; 4- piling exposed; 5- settled; 6- failed

Materials: 1- Concrete; 2- Stone masonry or drywall; 3- steel or metal; 4- wood

79. Abutment comments (eg. undermined penetration, unusual scour processes, debris, etc.):

$\mathbf{0}$

0.5

1

The right abutment has random voids below the base of the wall, exposing stones. Settlement at the upstream end of the wingwall near the old wingwall was evident.

80. Wingwalls:

Exist? Material? Scour Scour Exposure $\begin{aligned} & 81 . \\ & \text { Angle? Length? }\end{aligned}$ Condition? depth? depth?

USLWW:

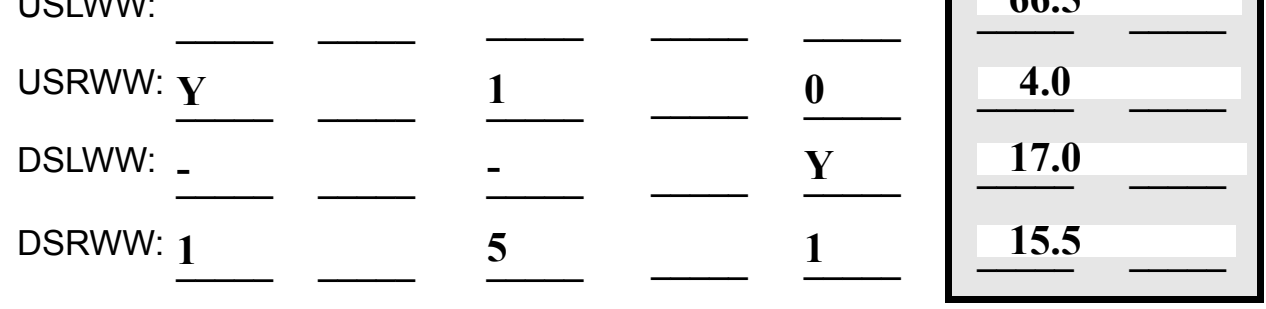

Wingwall materials: 1- Concrete; 2- Stone masonry or drywall; 3- steel or metal; 4- wood

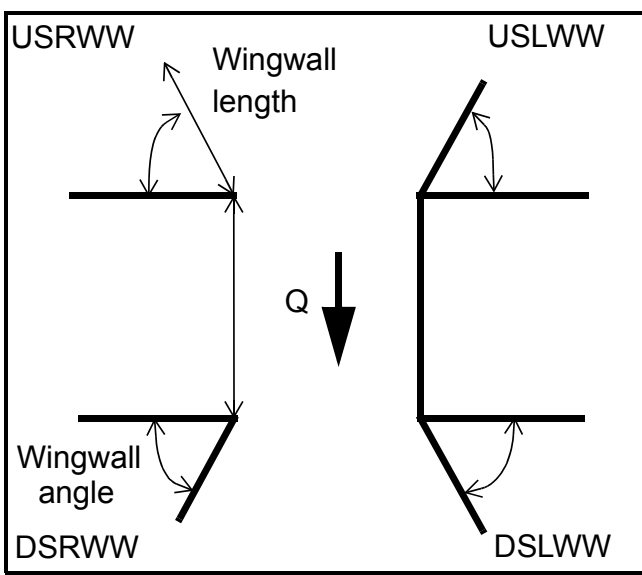

82. Bank / Bridge Protection:

\begin{tabular}{|l|l|l|l|l|l|l|l|c|}
\hline Location & USLWW & USRWW & LABUT & RABUT & LB & RB & DSLWW & DSRWW \\
\hline Type & $\mathbf{0}$ & $\mathbf{0}$ & $\mathbf{N}$ & - & $\mathbf{1}$ & - & $\mathbf{1}$ & $\mathbf{1}$ \\
\hline Condition & $\mathbf{Y}$ & - & - & - & $\mathbf{1}$ & - & $\mathbf{1}$ & $\mathbf{1}$ \\
\hline Extent & $\mathbf{1}$ & - & - & $\mathbf{2}$ & $\mathbf{0}$ & $\mathbf{2}$ & $\mathbf{3}$ & - \\
\hline
\end{tabular}

Bank / Bridge protection types: 0- absent; 1- < 12 inches; 2- < 36 inches; 3- < 48 inches; 4- < 60 inches; 
83. Wingwall and protection comments (eg. undermined penetration, unusual scour processes, etc.):

-
-
-
-
-
2
1
1
-
-
-

\section{Piers:}

84. Are there piers? 80. (Y or if $N$ type ctrl-n pr)

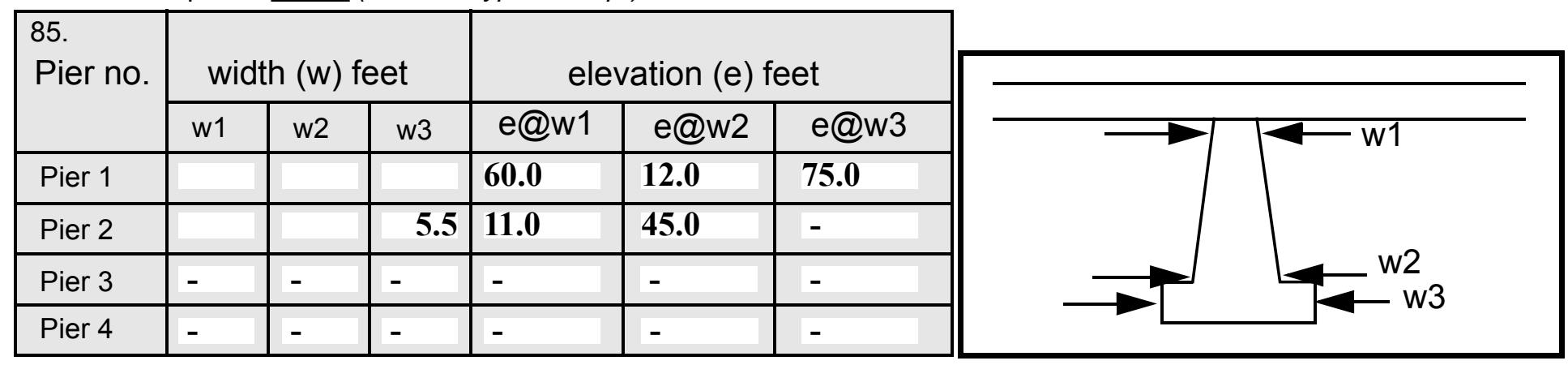

\begin{tabular}{|c|c|c|c|c|}
\hline Level 1 Pier Descr. & 1 & 2 & 3 & 4 \\
\hline 86. Location (BF) & The & ment & nearly & tled. \\
\hline 87. Type & upst & wing & par- & \\
\hline 88. Material & ream & wall & allel & \\
\hline 89. Shape & right & and & to & \\
\hline 90. Inclined? & wing & $\mathbf{a}$ & the & \\
\hline 91. Attack $\angle$ (BF) & wall & newe & right & \\
\hline 92. Pushed & con- & $\mathbf{r}$ & abut & \\
\hline 93. Length (feet) & - & - & - & - \\
\hline 94. \# of piles & sists & wing & ment & \\
\hline 95. Cross-members & of & wall & ; & \\
\hline 96. Scour Condition & the & exte & both & \\
\hline 97. Scour depth & older & ndin & have & $\mathbf{N}$ \\
\hline 98. Exposure depth & abut & g & set- & - \\
\hline
\end{tabular}

LFP, LTB, LB, MCL, MCM, MCR, RB, RTB, RFP

1- Solid pier, 2- column, 3- bent

1-Wood; 2- concrete; 3- metal; 4- stone

1- Round; 2- Square; 3- Pointed

Y-yes; $N$ - no

$L B$ or $R B$

0- none; 1- laterals; 2- diagonals; 3- both

0- not evident; 1- evident (comment);

2- footing exposed; 3- piling exposed;

4- undermined footing; 5- settled; 6- failed 
99. Pier comments (eg. undermined penetration, protection and protection extent, unusual scour processes, etc.):

-
-
-
-
-
-
-
-
-
-

100.

\section{E. Downstream Channel Assessment}

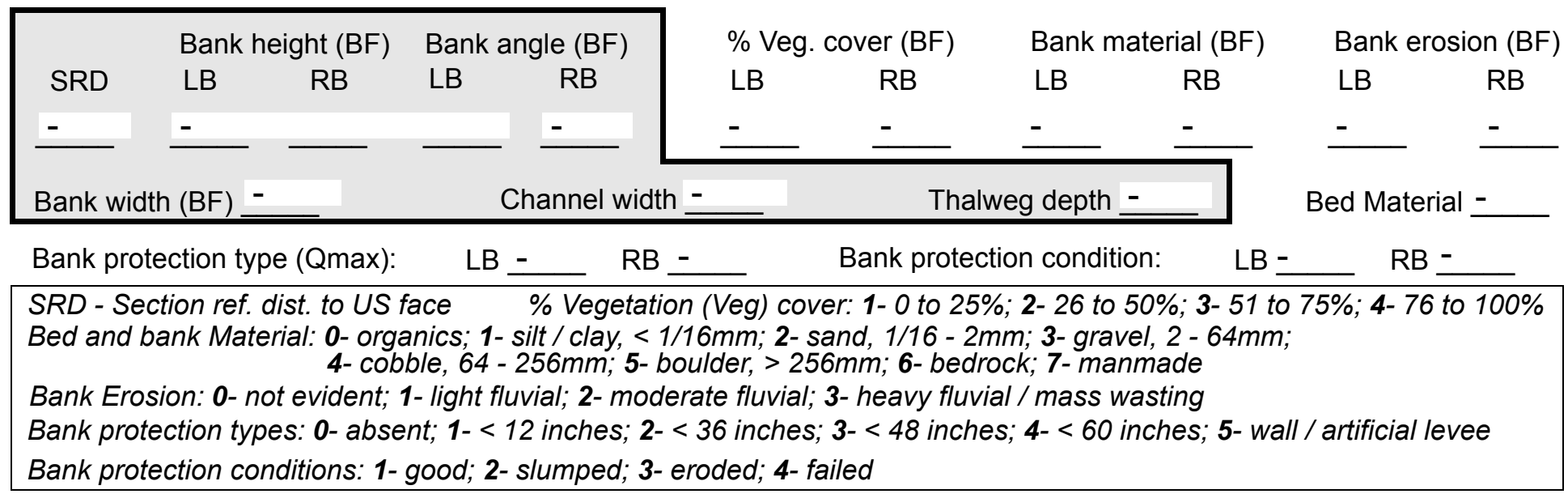

Comments (eg. bank material variation, minor inflows, protection extent, etc.):

$$
-
$$$$
-
$$$$
-
$$$$
-
$$$$
-
$$$$
-
$$$$
-
$$$$
-
$$

$-$

$-$

$-$

$-$

$-$

$-$

$-$

101. Is a drop structure present? _ _ ( or $N$, if $N$ type ctrl-n ds) 102. Distance: ___ feet 103. Drop: -_ feet 104. Structure material: ___ (1- steel sheet pile; 2- wood pile; 3- concrete; 4- other) 105. Drop structure comments (eg. downstream scour depth): 
106. Point/Side bar present? (Y or $N$. if $N$ type ctrl-n pb)Mid-bar distance:

Mid-bar width: -

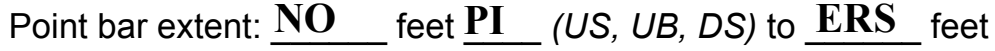
(US, UB, DS) positioned $\%$ LB to $\%$ RB Material:

Point or side bar comments (Circle Point or Side) note additional bars, material variation, status, etc.):

Is a cut-bank present? (Y or if $N$ type ctrl- $n$ cb) Where? 4 (LB or $R B)$

Mid-bank distance: 4

Cut bank extent: 63 feet 32 (US, UB, DS) to $\mathbf{0}$ feet 1 (US, UB, DS)

Bank damage: 34 (1-eroded and/or creep; 2- slip failure; 3- block failure)

Cut bank comments (eg. additional cut banks, protection condition, etc.):

2

0

1

-

$\underline{\text { Is channel scour present? }}$ Th (Y or if N type ctrl-n cs) Mid-scour distance: e left Scour dimensions: Length bank Width pro- Depth: tec- $\quad$ Positioned tion \%LB to beg \%RB Scour comments (eg. additional scour areas, local scouring process, etc.):

ins $20 \mathrm{ft}$ upstream of the bridge and extends $90 \mathrm{ft}$ downstream of the bridge.

Are there major confluences? Confluence 1: Distance Confluence 2: Distance

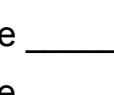

Confluence comments (eg. confluence name): ( $Y$ or if $N$ type ctrl-n $m c)$ Enters on ( $L B$ or $R B)$ (LB or $R B)$
How many?

Type (1- perennial; 2- ephemeral)

Type (1-perennial; 2- ephemeral)

\section{F. Geomorphic Channel Assessment}

107. Stage of reach evolution
1- Constructed

2- Stable

3- Aggraded

4- Degraded

5- Laterally unstable

6- Vertically and laterally unstable 
108. Evolution comments (Channel evolution not considering bridge effects; See HEC-20, Figure 1 for geomorphic descriptors):

$\mathbf{N}$

$-$

NO DROP STRUCTURE

Y

110

25

30

DS 


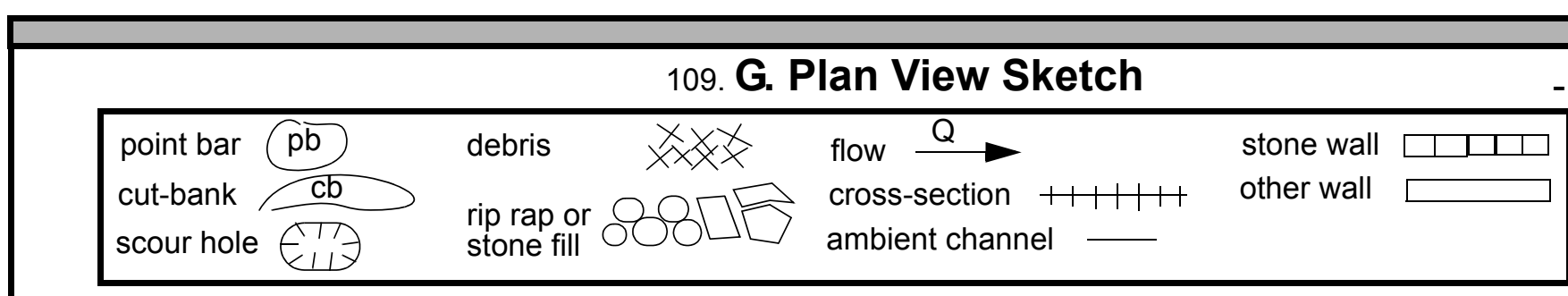


APPENDIX F:

SCOUR COMPUTATIONS 


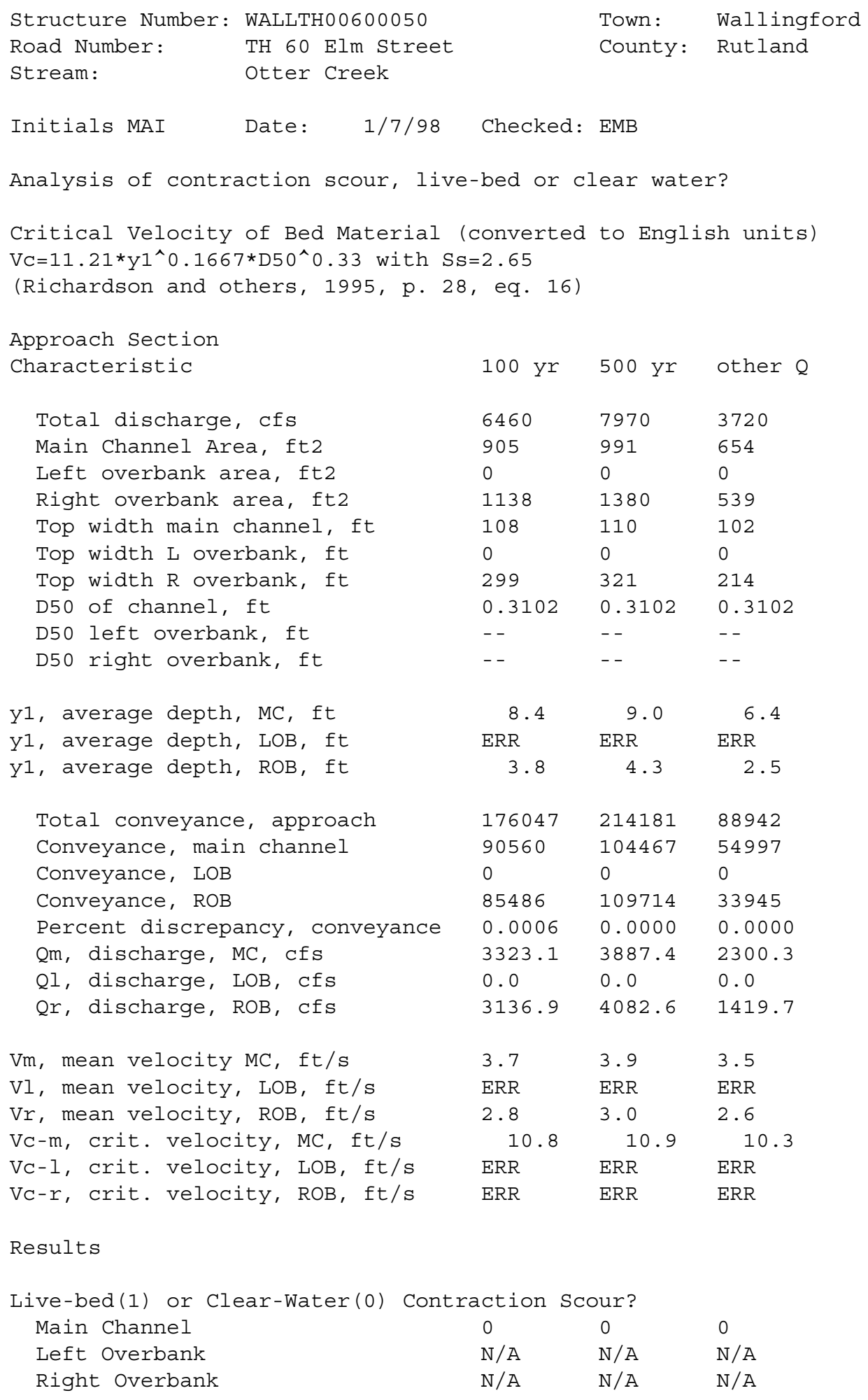


Clear Water Contraction Scour in MAIN CHANNEL

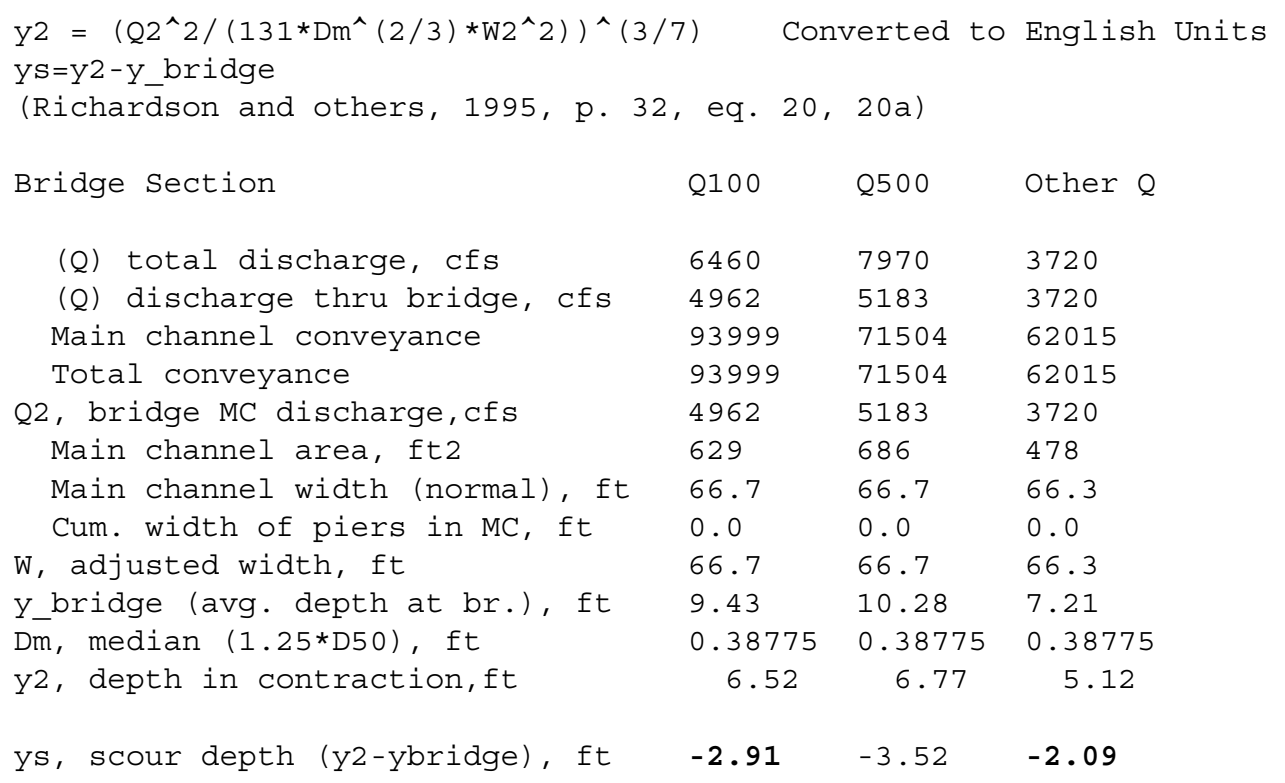

\begin{tabular}{|c|c|c|c|c|}
\hline \multicolumn{5}{|c|}{ Pressure Flow Scour (contraction scour for orifice } \\
\hline \multicolumn{5}{|c|}{$\begin{array}{l}\text { Umbrell pressure flow equation } \\
(\mathrm{Hb}+\mathrm{Ys}) / \mathrm{Ya}=1.1021 *[(1-\mathrm{w} / \mathrm{ya}) *(\mathrm{Va} / \mathrm{VC})] \wedge 0.6031 \\
(\text { Richardson and other, 1995, p. 144-146) }\end{array}$} \\
\hline & Q100 & Q500 & OtherQ & \\
\hline Q, total, cfs & 6460 & 7970 & 3720 & \\
\hline Q, thru bridge $\mathrm{MC}$, cfs & 4962 & 5183 & 3720 & \\
\hline Vc, critical velocity, ft/s & 10.81 & 10.95 & 10.34 & \\
\hline Va, velocity MC approach, ft/s & 3.67 & 3.92 & 3.52 & \\
\hline Main channel width (normal), ft & 66.7 & 66.7 & 66.3 & \\
\hline Cum. width of piers in MC, ft & 0.0 & 0.0 & 0.0 & \\
\hline W, adjusted width, ft & 66.7 & 66.7 & 66.3 & \\
\hline qbr, unit discharge, ft2/s & 74.4 & 77.7 & 56.1 & \\
\hline Area of full opening, ft2 & 629.0 & 686.0 & 478.0 & \\
\hline Hb, depth of full opening, ft & 9.43 & 10.28 & 7.21 & \\
\hline Fr, Froude number, bridge $\mathrm{MC}$ & 0 & 0.42 & 0 & \\
\hline Cf, Fr correction factor $(<=1.0)$ & 0.00 & 1.00 & 0.00 & \\
\hline **Area at downstream face, ft2 & $\mathrm{N} / \mathrm{A}$ & 676.1 & $\mathrm{~N} / \mathrm{A}$ & \\
\hline **Hb, depth at downstream face, ft & $\mathrm{N} / \mathrm{A}$ & 10.14 & $\mathrm{~N} / \mathrm{A}$ & \\
\hline **Fr, Froude number at DS face & ERR & 0.42 & ERR & \\
\hline
\end{tabular}




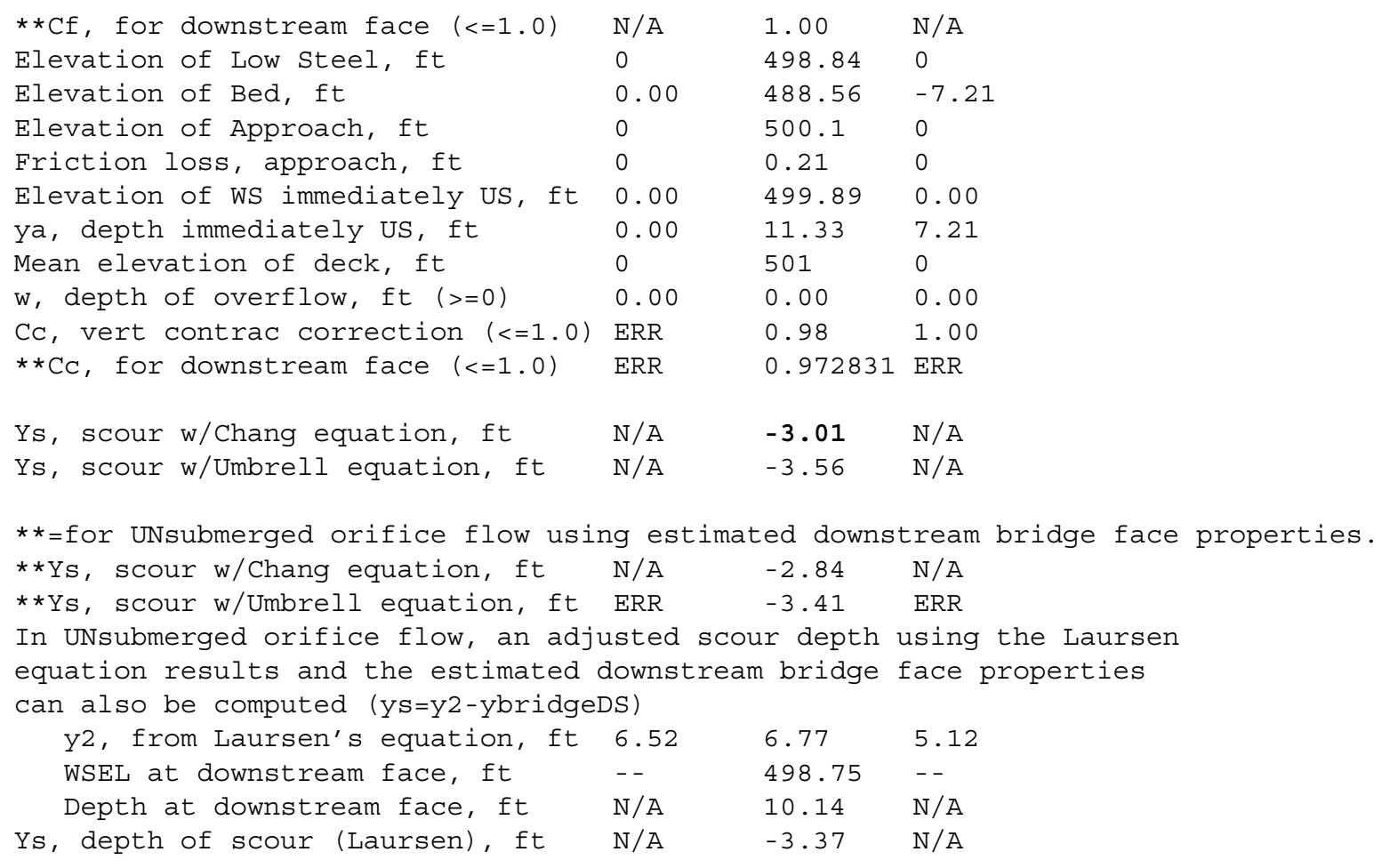

\section{Armoring}

$\mathrm{DC}=\left[\left(1.94 * \mathrm{~V}^{\wedge} 2\right) /(5.75 * \log (12.27 * \mathrm{Y} / \mathrm{D} 90))^{\wedge} 2\right] /[0.03 *(165-62.4)]$

Depth to Armoring $=3 *(1 / \mathrm{PC}-1)$

(Federal Highway Administration, 1993)

$\begin{array}{rlll}\text { Downstream bridge face property } & 100-\mathrm{yr} & 500-\mathrm{yr} & \text { Other Q } \\ \text { Q, discharge thru bridge MC, cfs } & 4962 & 5183 & 3720 \\ \text { Main channel area (DS), ft2 } & 629 & 676.1 & 478 \\ \text { Main channel width (normal), ft } & 66.7 & 66.7 & 66.3 \\ \text { Cum. width of piers, ft } & 0.0 & 0.0 & 0.0 \\ \text { Adj. main channel width, ft } & 66.7 & 66.7 & 66.3 \\ \text { D90, ft } & 0.5236 & 0.5236 & 0.5236 \\ \text { D95, ft } & 0.5906 & 0.5906 & 0.5906 \\ \text { DC, critical grain size, ft } & 0.2159 & 0.1985 & 0.2326 \\ \text { PC, Decimal percent coarser than Dc } & 0.810 & 0.857 & 0.748 \\ \text { Depth to armoring, ft } & & & \\ \end{array}$

\section{Abutment Scour}

Froehlich's Abutment Scour

$\mathrm{Ys} / \mathrm{Y} 1=2.27 * \mathrm{~K} 1 * \mathrm{~K} 2 *\left(\mathrm{a}^{\prime} / \mathrm{Y} 1\right)^{\wedge} 0.43 * \mathrm{Fr} 1^{\wedge} 0.61+1$

(Richardson and others, 1995, p. 48, eq. 28)

\begin{tabular}{|c|c|c|c|c|c|c|}
\hline \multirow[b]{2}{*}{ Characteristic } & \multicolumn{2}{|c|}{ Left Abutment } & \multicolumn{4}{|c|}{ Right Abutment } \\
\hline & 100 yr Q & $500 \mathrm{yr}$ & Other Q & $100 \mathrm{yr}$ & $500 \mathrm{yr}$ & Other Q \\
\hline (Qt), total discharge, cfs & 6460 & 7970 & 3720 & 6460 & 7970 & 3720 \\
\hline a', abut.length blocking flow, ft & 19.9 & 21.1 & 13.7 & 42.5 & 42.5 & 42.9 \\
\hline Ae, area of blocked flow ft 2 & 105.06 & 122.26 & 54.07 & 239.58 & 273.16 & 139.19 \\
\hline $\begin{array}{l}\text { Qe, discharge blocked abut., cfs } \\
\text { (If using Qtotal_overbank to }\end{array}$ & 193.02 & 247.3 & 91.01 & -- & -- & -- \\
\hline Ve, $(\mathrm{Qe} / \mathrm{Ae}), \mathrm{ft} / \mathrm{s}$ & 2.57 & 2.02 & 1.68 & 2.80 & 3.01 & 2.58 \\
\hline
\end{tabular}




\begin{tabular}{|c|c|c|c|c|c|c|}
\hline ya, depth of $f / p$ flow, ft & 5.28 & 5.79 & 3.95 & 5.64 & 6.43 & 3.24 \\
\hline $\begin{array}{l}- \text {-Coeff., K1, for abut. type }(1.0 \\
\text { K1 }\end{array}$ & $\begin{array}{l}\text { verti } \\
0.82\end{array}$ & $\begin{array}{l}.82, \mathrm{ve} \\
0.82\end{array}$ & $\begin{aligned} & \text { cti. w/ w } \\
& 0.82\end{aligned}$ & $\begin{array}{l}\text { ngwall } \\
\quad 0.82\end{array}$ & $\begin{array}{c}0.55, \mathrm{spi} \\
0.82\end{array}$ & $\begin{array}{l}\text { llthru) } \\
0.82\end{array}$ \\
\hline --Angle (theta) of embankment $(<9$ & if abu & points & $\mathrm{DS} ;>90 \mathrm{i}$ & abut. & points US) & \\
\hline theta & 95 & 95 & 95 & 85 & 85 & 85 \\
\hline $\mathrm{K} 2$ & 1.01 & 1.01 & 1.01 & 0.99 & 0.99 & 0.99 \\
\hline Fr, froude number $\mathrm{f} / \mathrm{p}$ flow & 0.168 & 0.148 & 0.149 & 0.245 & 0.250 & 0.277 \\
\hline ys, scour depth, ft & 11.18 & 11.70 & 7.91 & 16.16 & 17.91 & 11.56 \\
\hline \multicolumn{7}{|c|}{$\begin{array}{l}\mathrm{ys}=4 * \mathrm{Fr} r^{\wedge} 0.33 * \mathrm{Y} 1 * \mathrm{~K} / 0.55 \\
(\mathrm{Richardson} \text { and others, 1995, p. 49, eq. 29) }\end{array}$} \\
\hline$a^{\prime}$ (abut length blocked, ft) & 19.9 & 21.1 & 13.7 & 42.5 & 42.5 & 42.9 \\
\hline y1 (depth f/p flow, ft) & 5.28 & 5.79 & 3.95 & 5.64 & 6.43 & 3.24 \\
\hline$a^{\prime} / y 1$ & 3.77 & 3.64 & 3.47 & 7.54 & 6.61 & 13.22 \\
\hline Skew correction (p. 49, fig. 16) & 1.01 & 1.01 & 1.01 & 0.98 & 0.98 & 0.98 \\
\hline Froude no. f/p flow & 0.17 & 0.15 & 0.15 & 0.25 & 0.25 & 0.28 \\
\hline \multirow{3}{*}{$\begin{array}{c}\text { Ys w/ corr. factor } \mathrm{Kl} / 0.55: \\
\text { vertical } \\
\text { vertical w/ ww's } \\
\text { spill-through }\end{array}$} & ERR & ERR & ERR & ERR & ERR & $\mathrm{ERR}$ \\
\hline & ERR & ERR & ERR & ERR & ERR & ERR \\
\hline & ERR & ERR & ERR & ERR & ERR & ERR \\
\hline \multicolumn{7}{|l|}{ Abutment riprap Sizing } \\
\hline \multirow{3}{*}{\multicolumn{7}{|c|}{$\begin{array}{l}\text { Isbash Relationship } \\
\mathrm{D} 50=\mathrm{Y}^{\star} \mathrm{K} * \mathrm{Fr} r^{\wedge} 2 /(\mathrm{Ss}-1) \text { and } \mathrm{D} 50=\mathrm{Y}^{*} \mathrm{~K} *(\mathrm{Fr} \wedge 2)^{\wedge} 0.14 /(\mathrm{Ss}-1) \\
\text { (Richardson and others, 1995, p112, eq. 81,82) }\end{array}$}} \\
\hline & & & & & & \\
\hline & & & & & & \\
\hline Characteristic & Q100 & Q500 & Other $Q$ & Q100 & Q500 & Other $\mathrm{Q}$ \\
\hline Fr, Froude Number & 0.51 & 0.42 & 0.55 & 0.51 & 0.42 & 0.55 \\
\hline y, depth of flow in bridge, ft & 9.43 & 10.14 & 7.21 & 9.43 & 10.14 & 7.21 \\
\hline Median stone Diameter for riprap & : left & utment & & right & abutment, & ft \\
\hline Fr<=0.8 (vertical abut.) & 1.52 & 1.11 & 1.35 & 1.52 & 1.11 & 1.35 \\
\hline Fr>0.8 (vertical abut.) & ERR & ERR & ERR & $E R R$ & $E R R$ & ERR \\
\hline
\end{tabular}


